Made available courtesy of UNIVERSITY OF CHICAGO.

\title{
Advance Notice and Postdisplacement Joblessness
}

\author{
Christopher J. Ruhm, University of North Carolina \\ at Greensboro
}

This article investigates whether prenotification decreases postdisplacement joblessness. Reduced-form estimates indicate that lengthy written notice is associated with small increases in the probability of avoiding nonemployment but with no decline in average durations. Significant reductions are found, however, for household heads, women, nonwhites, and in local labor markets with high unemployment rates. A new method is developed to control for the endogeneity of voluntarily provided advance notice. This procedure suggests that previous research substantially overstates the degree to which prenotification reduces nonemployment and indicates that the actual decrease is between 2 and 5 working days.

\section{Introduction}

During the last decade, the United States has witnessed a lively policy debate concerning the efficacy of legislation mandating employer advance notification of plant shutdowns and mass layoffs. More than 125 bills relating to plant closings were presented in 30 states between 1975 and 1983, and over 40 laws have been proposed at the federal level since 1979. Culminating this effort, the Worker Assistance and Retraining Notification Act (Public Law 100-379), which requires employers to provide 60 days' advance notice of plant closures and of large-scale layoffs, was passed into

I would like to thank Ronald Ehrenberg, Lori Kletzer, Kevin Lang, Adam Seitchik, and Andrew Weiss for helpful comments and Julia Watson for her outstanding research assistance. Financial support was provided by the U.S. Department of Labor, Employment and Training Administration. The usual disclaimer applies.

[Journal of Labor Economics, 1992, vol. 10, no. 1]

(c) 1992 by The University of Chicago. All rights reserved. 
law in 1988. Although the legislation contains numerous exemptions, with its passage the United States has joined virtually all other ind ustrialized countries in regulating enterprise shutdowns and mass terminations. 1

This activity has taken place in the absence of reliable information on either the benefits or costs of mandatory notice. The situation has recently improved, however, with the release of several studies using nationally representative data from special Displaced Workers Supplements (DWS) to the January 1984 and January 1986 Current Population Surveys (CPS) (see, e.g., Addison and Portugal 1987a; Podgursky and Swaim 1987; Ehrenberg and Jakubson 1988; Kletzer 1989).2 This work suggests that prior notification decreases expected joblessness by around 1 month, mostly by raising the probability of avoiding nonemployment altogether. There is little evidence of reduced joblessness for persons who are unable to obtain immediate reemployment. 3

Unfortunately, the usefulness of this research is lessened because of limitations inherent in the data sources and methodological approaches. Two data shortcomings are particularly troublesome. First, because the 1984 and 1986 DWS provide no information on either the duration or type of notice, investigators are unable to distinguish among written notification, verbal announcements, and expectations of job loss in the absence of any type of notice. They also cannot differentiate the effects of short versus lengthy notice. Second, data on joblessness are limited to total weeks out of work between the date of displacement and the surveys, whether this transpires in a single spell or in multiple occurrences punctuated by short periods of employment. This is problematic for econometric duration models that typically require continuous spell information. Furthermore, for policy purposes, we are often interested in the initial period of joblessness.

Previous studies have also paid relatively little attention to the potential endogeneity of voluntarily provided advance notice and have focused on average impacts rather than on the potentially large variations across worker, job, and geographic characteristics. Even if the average impact of early warning is fairly small, large benefits might accrue to population

1. Companies are required to provide advance notice and to negotiate with their employees and governments over layoffs in Canada and most Western European countries. By contrast, before 1988, only three states (Maine, Wisconsin, and Hawaii) had legislated any form of mandatory advance notice, with three others (Massachusetts, Maryland, and Michigan) having voluntary programs encouraging companics to provide warning or to continue employee benefits.

2. Also see Folbre, Leighton, and Roderick (1984) for an earlier investigation using enterprise-level data for the state of Maine.

3. Because the DWS does not distinguish between unemployment and nonparticipation in the labor force, the terms "joblessness" or "nonemployment" (rather than "unemployment") will be used throughout. 
subgroups experiencing reemployment difficulties or for those whose joblessness raises particular concern. 4

The failure of earlier work to distinguish between informal and written notification is problematic for several reasons. First, the two types of notice need not change workers' estimates of the probabilities of impending job terminations in the same way. If they do not, their impact on predisplacement search behavior and subsequent joblessness will differ. Second, since workers unusually well informed about labor market conditions are relatively likely to both anticipate displacements and become rapidly reemployed, estimates of the effects of informal notice are likely to overstate the benefits of formal notification. Third, some respondents may foresee their displacements prior to receiving written notice. If they act on these expectations by searching for new work, then the subsample acquiring formal notice will be disproportionately composed of persons who have looked for but failed to obtain new positions. These individuals will also typically have relatively long expected durations of postdisplacement joblessness.

This study improves on each of the above shortcomings. A newly available data set ( the 1988 DWS) is utilized that contains information on the type and timing of notice and on the duration of the initial spell of joblessness.5 Reduced-form estimates are obtained for a model that includes full interactions between advance notice and the nonnotification covariates, as well as for a more conventional equation where early warning influences only the regression intercept. Finally, a new method is developed and implemented to provide endogeneity-corrected estimates of the effects of endogenously provided advance notification.

Four primary findings are highlighted. First, earlier research substantially overstates the extent to which prenotification reduces postdisplacement joblessness. This occurs both because of the inability to distinguish between formal and informal notice, using previously available data sets, and because of the failure to correct for the endogeneity of advance notice.

Second, although reduced-form regressions continue to show that both informal notice and lengthy formal notification are associated with increased probabilities of avoiding joblessness altogether, only the former are also correlated with shorter average nonemployment durations.

Third, substantial differences are observed across population subgroups. Of particular interest, formal notice received more than 2 months before the displacement is associated with significantly reduced joblessness for

4. Podgursky and Swaim (1987) and Ehrenberg and Jakubson (1988) have allowed for some demographic group variations but have not included a full set of interactions. 
household heads, females, nonwhites, and displaced workers residing in local labor markets with high rates of unemployment.

Fourth, the endogeneity of voluntarily provided notice is important. Formal warnings are disproportionately obtained by individuals possessing unobserved characteristics correlated with low reemployment probabilities, informal notification by workers with higher hazard rates out of nonemployment. After implementing a new procedure to account for this unobserved heterogeneity, prenotification is calculated to reduce postdisplacement joblessness by an average of between 2 days and 1 week. This estimate is only one-fourth to one-eighth as large as that typically obtained in previous research.

\section{Data}

This article uses data from the Displaced Worker Supplement to the January 1988 Current Population Survey. The 1988 DWS contains retrospective information on previous job histories and on labor market status for a nationally representative sample of workers suffering permanent job loss between 1983 and January 1988. Included in the supplement are persons leaving their jobs prior to displacement (either to begin new positions or search for work), as well as those remaining with their predisplacement employers until the termination date. 6

The sample analyzed includes workers between the ages of 25 and 60 who, at the survey date, lost jobs as the result of a business failure, plant closure or relocation, or a layoff resulting from slack work or from a position or shift being abolished. Persons terminating positions in agriculture, construction, or the armed forces are excluded, as are previously self-employed individuals and those displaced in the month of the survey.

The 1988 DWS includes three questions pertaining to advance notice. The first inquires whether the worker did "expect a layoff or had received advance notice of a layoff or plant or business closing." This inquiry, which contains no information on either the type or timing of notice, was

6. Information from the DWS is obtained for regular CPS respondents who answer affirmatively the question, "In the last 5 years, that is, since January 1983, has (he/ she) lost or left a job because of a plant closing, an employer going out of business, a layoff from which (he/she) was not recalled, or other similar reasons?" (emphasis added). Two types of evidence indicate that early job leavers answer this question in such a way as to be included in the supplement. First, more than an eighth of the sample analyzed below is out of work for less than 1 week before starting a new job. Such abbreviated joblessness is likely to be common only for persons finding new employment prior to displacement. Second, the 1984 and 1986 DWS supplements, which use identical inclusion criteria to the 1988 supplement, obtain a substantial proportion of affirmative replies to a question asking whether the worker did "leave that job before (he/she) would have been laid off." For example, Fallick (1991), who focuses specifically on this issue using the 1986 DWS, finds that $9.3 \%$ of displaced workers involved in plant closings (and $16.8 \%$ of this group who also receive advance notice) are premature job leavers. 
also incorporated in the 1984 and 1986 DWS supplements and provided the only information on early notification available to previous researchers. The two questions added to the 1988 DWS ask if the respondent had "been given written advance notice that the business would be closed or that he/ she would be laid off" and, if so, "how long before he/she was to be laid off did he/she receive that notice?" Responses to the last question were categorized into the following ranges: less than 1, 1.2, and greater than 2 months.

The regression analysis includes covariates for a wide variety of individual, job, and geographic characteristics. These are described in the Appendix. In addition to data obtained from the DWS and attached CPS, regressors were constructed using information from other sources. Variables indicating the state, industry, and occupation unionization rate and a dummy variable for residing in right-to-work states were included to proxy for collective bargaining status on the predisplacement job. The occupation unemployment rate, state or standard metropolitan statistical area (SMSA) unemployment rate, and the average industry employment growth rate were added to account for differences in economic conditions across localities and employment sectors.7 Variables measuring the predisplacement wage residual and predicted probability of receiving unemployment insurance benefits ( conditional on positive unemployment) were also included.8

\section{Frequency of Advance Notice}

A slight majority (53.0\%) of displaced workers anticipated their job loss, but only $15.1 \%$ received written advance notice of it, and just $5.0 \%$ were provided with formal announcements at least 2 months before the termination (see table 1, row 1).9 The percentage of workers with any

7. The DWS identifies geographic location at the survey date rather than at the time of displacement. Since approximately $19 \%$ of the sample changed location between the latter and former period, this could lead to biased estimates of local labor market effects. To the extent that respondents are more likely to move out of depressed areas and into locations with low unemployment, this leads to an understatement of the impact of regional conditions. Ehrenberg and Jakubson (1988) and Howland and Peterson (1988) compare estimates with and without movers included in the sample and conclude that these biases are quite small.

8. Some previous researchers (e.g., Addison and Portugal 1987a) have controlled for the actual receipt of unemployment insurance (UI) rather than the conditional probability. The receipt of UI is endogenous, however, since workers avoiding nonemployment are generally ineligible for benefits. Persons receiving benefits will therefore almost certainly have longer average joblessness, even in the absence of a true UI effect.

9. These percentages were calculated directly from the DWS sample. Virtually identical percentages were obtained after adjusting for population weights. The weighted proportions are that $52.3 \%$ expected displacement, $15.1 \%$ received written notice, and $5.1 \%$ obtained written notification exceeding 2 months. 
Table 1

Probability of Receiving Advance Notice and Mean Characteristics by Type of Notice

\begin{tabular}{|c|c|c|c|c|c|c|c|}
\hline & \multirow{3}{*}{$\begin{array}{c}\text { All } \\
\text { Workers }\end{array}$} & \multirow{3}{*}{$\begin{array}{l}\text { No } \\
\text { Notice }\end{array}$} & \multirow{3}{*}{$\begin{array}{l}\text { Received } \\
\text { Notice }\end{array}$} & \multicolumn{4}{|c|}{ Type of Notice } \\
\hline & & & & \multirow[b]{2}{*}{ Unwritten } & \multicolumn{3}{|c|}{ Written (No. of Months) } \\
\hline & & & & & $<1$ & $1-2$ & $>2$ \\
\hline \multicolumn{8}{|l|}{$\begin{array}{l}\text { Probability of } \\
\text { receiving }\end{array}$} \\
\hline $\begin{array}{l}\text { notice } \\
\text { Personal }\end{array}$ & $\cdots$ & $\cdots$ & .530 & .379 & .061 & .040 & .050 \\
\hline characteristics: & & & & & & & \\
\hline Age (years) & 38.2 & 37.8 & 38.5 & 38.4 & 37.6 & 38.7 & 40.1 \\
\hline $\begin{array}{l}\text { Education } \\
\text { (years) }\end{array}$ & 12.9 & 13.0 & 12.9 & 12.8 & 12.9 & 13.1 & 13.2 \\
\hline Married (\%) & 65.4 & 63.3 & 67.3 & 67.7 & 66.7 & 61.4 & 69.7 \\
\hline Household head & & & & & & & \\
\hline$(\%)$ & 64.6 & 65.8 & 63.6 & 61.9 & 68.3 & 73.0 & 63.2 \\
\hline Nonwhite (\%) & 13.4 & 13.9 & 12.2 & 11.3 & 16.1 & 14.7 & 12.9 \\
\hline Female (\%) & 42.8 & 42.1 & 43.4 & 43.4 & 42.6 & 43.6 & 44.3 \\
\hline No. of children & 1.74 & 1.73 & 1.74 & 1.72 & 1.84 & 1.83 & 1.72 \\
\hline No. of earners & 1.19 & 1.14 & 1.23 & 1.22 & 1.21 & 1.16 & 1.42 \\
\hline Predisplacement & & & & & & & \\
\hline $\begin{array}{l}\text { Seniority (years) } \\
\text { Health }\end{array}$ & 5.2 & $4.5^{\circ}$ & 5.9 & 5.4 & 5.4 & 6.7 & 9.3 \\
\hline $\begin{array}{l}\text { insurance (\%) } \\
\text { Log weekly }\end{array}$ & 65.0 & 59.0 & 70.3 & 65.8 & 77.5 & 77.3 & 89.6 \\
\hline wage & 5.67 & 5.66 & 5.67 & 5.62 & 5.74 & 5.82 & 5.90 \\
\hline Plant closing (\%) & 52.1 & 44.8 & 58.6 & 58.6 & 43.0 & 65.6 & 72.6 \\
\hline Blue collar (\%) & 37.3 & 35.5 & 38.9 & 38.9 & 44.6 & 35.0 & 34.8 \\
\hline Part-time (\%) & 9.55 & 9.35 & 9.73 & 11.2 & 6.58 & 8.28 & 3.76 \\
\hline $\begin{array}{l}\text { Industry } \\
\text { employment } \\
\text { growth (\%) }\end{array}$ & 1.08 & 1.24 & .94 & 1.01 & .60 & 1.21 & .64 \\
\hline $\begin{array}{l}\text { Occupation } \\
\text { unemploy- } \\
\text { ment rate }(\%)\end{array}$ & 6.58 & 6.26 & 6.69 & 6.69 & 7.46 & 6.33 & 6.03 \\
\hline $\begin{array}{l}\text { Industry } \\
\text { unionization } \\
\text { rate }(\%)\end{array}$ & 24.9 & 23.8 & 25.9 & 25.4 & 29.3 & 24.5 & 27.1 \\
\hline $\begin{array}{l}\text { Occupation } \\
\text { unionization } \\
\text { rate }(\%)\end{array}$ & 24.3 & 23.4 & 25.2 & 24.8 & 28.4 & 24.0 & 25.0 \\
\hline $\begin{array}{l}\text { Geographic } \\
\text { characteristics: } \\
\text { State }\end{array}$ & & & & & & & \\
\hline $\begin{array}{l}\text { unionization } \\
\text { rate }(\%) \\
\text { Right-to-work }\end{array}$ & 20.5 & 20.3 & 20.7 & 20.3 & 21.0 & 21.5 & 23.1 \\
\hline $\begin{array}{l}\text { state }(\%) \\
\text { Area unemploy- }\end{array}$ & 33.8 & 34.6 & 33.0 & 35.5 & 33.3 & 25.1 & 20.4 \\
\hline ment rate $(\%)$ & 7.39 & 7.42 & 7.36 & 7.39 & 7.28 & 7.61 & 7.09 \\
\hline$N$ & 4,058 & 1,907 & 2,151 & 1,538 & 248 & 162 & 203 \\
\hline
\end{tabular}


type of notice is similar to the $55 \%$ and $56 \%$, respectively, calculated by Ehrenberg and Jakubson (1988) from the 1984 and 1986 DWS. The proportion with written advance notice is also close to that in a General Accounting Office (GAO) survey of representative establishments; analysis of the GAO data revealed that $81 \%$ of workers received less than 1 month's warning and only 5\% obtained over 90 days' notice in 1983-84 (U.S. General Accounting Office 1987).10 The GAO defines notice to include specific information (whether verbal or written) concerning the date of displacement and workers affected. The similarity of the GAO numbers to those for written notification in the DWS suggests that precise verbal information is rarely provided.11 This implies that most workers who report that they "expected" their jobs to terminate, in the absence of written notice, probably also lacked specific unwritten information on when and whether the layoff would occur.

Notified workers tended to be older, had greater job seniority, and more often worked in slow-growing industries or occupations than their nonnotified counterparts. They more frequently lost jobs that provided group health insurance and were located in industries, occupations, and states with relatively high unionization rates. Nonnotified individuals were relatively often nonwhite and displaced because of partial layoffs rather than plant closings (see table 1, cols. 2 and 3 ).

The distinction between formal and informal notice is sometimes important. Nonwhites received written notification more often than whites but less frequently obtained informal warnings. The relative probabilities of acquiring lengthy formal notice were much greater for respondents with high job seniority, group health insurance coverage, and full-time work and for those affected by plant closings. Thus, $89.6 \%$ of displaced persons receiving more than 2 months' written notice left positions providing group health insurance, $72.6 \%$ were involved in plant closings, and the average job tenure of this group exceeded 9 years. The corresponding percentages for nonnotified respondents were $59.0 \%$ and $44.8 \%$, respectively, and their mean seniority was just 4.5 years.

Appendix table Al shows the results of maximum-likelihood probit and ordered probit regressions where the dependent variables represent various types of advance notice. 12 These regressions show that, in addition to the

10. See Brown (1987) for further discussion of the GAO study. A recent Conference Board survey (Berenbeim 1986) suggests that advance notice is provided more frequently. These findings are questionable, however, because of the nonrepresentativeness of the sample and frequency of nonresponse.

11. If specific unwritten notices were provided with any frequency, then the GAO percentages would be much higher than those for written notification in the DWS.

12. The dependent variable in the ordered probit model equals zero, one, two, and three for persons receiving no, less than 1, 1-2, and over 2 months' written notice, respectively. 
above-mentioned groups, written notice is particularly probable for educated persons, respondents in multiple earner families, recipients of positive wage residuals, and those residing in tight local labor markets or states with legislation mandating advance notice.

There is evidence that prenotification is provided nonrandomly. To some degree this is not surprising. Unionized and long-seniority workers are expected to have high probabilities of being notified. That advance notice propensities also increase with education, wage residuals, number of earners in the household, health insurance coverage probabilities, and economic health of the local labor market suggests that prenotification is a normal good that workers demand more of as their compensation increases.

\section{Advance Notice and Joblessness: Descriptive Information}

Most workers experience significant nonemployment following permanent job losses. For example, Ruhm (1991a) calculates that the average displacement leads to approximately a 12 -week increase in unemployment, Dyer a 2-year period. Adding in the extra time out of work occurring during periods of labor force nonparticipation and that which would have been expected even in the absence of the termination (e.g., due to temporary Layoffs), total postdisplacement joblessness is significantly greater. Respondents in the 1988 DWS averaged 27.4 weeks out of work in the initial spell of nonemployment; $35.4 \%$ were jobless more than 6 months, and $12.8 \%$ for over 1 year (table 2, col. 1). 13

Notified workers avoided joblessness more frequently than their counterparts and had a greater chance of being reemployed at the survey date.14 Of this group, $13.9 \%$ experienced less than 1 week of postdisplacement joblessness, compared to 9.6 percent of their nonnotified peers (table 2, row 2). In January 1988, $74.7 \%$ of the former group were reemployed, versus $71.5 \%$ of the latter (see table 2, row 9). Workers receiving over a month of written advance notice were even more likely to find immediate reemployment.

There is scant evidence, however, that prior notification substantially reduces the incidence of extended joblessness. An identical 33.5\% of nonnotified and notified respondents were out of work for at least 6 months; among the various categories of written notice, the corresponding probabilities ranged from $33.9 \%$ to $37.8 \%$ (see table 2, rows 6 and 7).

13. These calculations underestimate the extent of joblessness since reports are top-coded at 99 weeks and are censored for persons continuously out of work between the employment termination and survey date. Similar findings for the 1984 and 1986 DWS are presented in Flaim and Sehgal (1985); Horvath (1987); and Podgursky and Swaim (1987).

14. Respondents are defined to "avoid joblessness" if they become reemployed within 1 week of the displacement. 
Table 2

Weeks of Postdisplacement Joblessness and Survey Date Employment Status by Type of Advance Notice

\begin{tabular}{|c|c|c|c|c|c|c|c|}
\hline & \multirow{3}{*}{$\begin{array}{c}\text { All } \\
\text { Workers } \\
(\%)\end{array}$} & \multirow{3}{*}{$\begin{array}{c}\text { No } \\
\text { Notice } \\
(\%)\end{array}$} & \multirow{3}{*}{$\begin{array}{l}\text { Received } \\
\text { Notice } \\
(\%)\end{array}$} & \multicolumn{4}{|c|}{ Type of Notice (\%) } \\
\hline & & & & \multirow[b]{2}{*}{ Unwritten } & \multicolumn{3}{|c|}{$\begin{array}{c}\text { Written } \\
\text { (No. of Months) }\end{array}$} \\
\hline & & & & & $<1$ & $1-2$ & $>2$ \\
\hline \multicolumn{8}{|l|}{ Weeks of joblessness: } \\
\hline Mean no. of weeks: & 27.4 & 28.4 & 26.5 & 25.9 & 28.5 & 27.8 & 26.9 \\
\hline$<1$ & 11.9 & 9.6 & 13.9 & 13.7 & 8.9 & 16.1 & 20.4 \\
\hline $1-4$ & 22.0 & 23.0 & 21.0 & 21.8 & 21.9 & 17.9 & 16.9 \\
\hline $5-12$ & 18.2 & 20.0 & 16.5 & 16.9 & 18.6 & 15.3 & 11.9 \\
\hline $13-26$ & 14.5 & 13.9 & 15.1 & 15.4 & 13.8 & 16.7 & 12.9 \\
\hline $27-52$ & 20.6 & 20.1 & 21.1 & 20.4 & 23.1 & 22.2 & 22.9 \\
\hline$>52$ & 12.8 & 13.4 & 12.4 & 11.9 & 13.8 & 11.7 & 14.9 \\
\hline Censored spells & 19.3 & 19.8 & 18.8 & 18.6 & 20.2 & 16.7 & 20.9 \\
\hline \multicolumn{8}{|l|}{$\begin{array}{l}\text { Survey date employment } \\
\text { status: }\end{array}$} \\
\hline Employed & 73.2 & 71.5 & 74.7 & 74.8 & 72.7 & 79.1 & 73.1 \\
\hline Unemployed & 15.4 & 16.6 & 14.3 & 14.1 & 15.7 & 9.8 & 17.4 \\
\hline Out of labor force & 11.5 & 12.0 & 11.0 & 11.1 & 11.7 & 11.0 & 9.5 \\
\hline
\end{tabular}

NOTE.-Joblessness is measured as the number of weeks out of work until the first spell of new employment or until survey date for censored spells. Joblessness set to 28 weeks for persons displaced in 1987 with nonemployment spells still in progress.

Males, whites, and workers displaced by plant closings have shorter spells of joblessness than their counterparts and are more likely to move directly into new jobs (see table 3 ). They are also less likely to remain out of work for 6 months or longer. The pattern across types of advance notice is similar for the various demographic groups, although lengthy written announcements are associated with relatively large reductions in nonemployment for nonwhites and sizable increases in the likelihood that females and laid-off workers will avoid joblessness.

\section{Evaluating the Effects of Advance Notice}

Advance notice has the potential of reducing nonemployment durations by allowing predisplacement search. Following Lancaster (1979), I specify the probability that an individual leaves joblessness over the short interval $[t, t+d t]$ by

$$
h(t) d(t)=\{1-G[\tilde{w}(t)]\} r(t) d t,
$$

where $h(\cdot)$ is the hazard rate, $G(\cdot)$ the distribution function of wage offers, $r(\cdot)$ the rate at which wage offers are received, and $\tilde{w}$ the reservation wage that is obtained from a model of search.

The hazard rate can be expressed in terms of the underlying density and distribution functions, $f(\cdot)$ and $F(\cdot)$, as 
Type of Notice

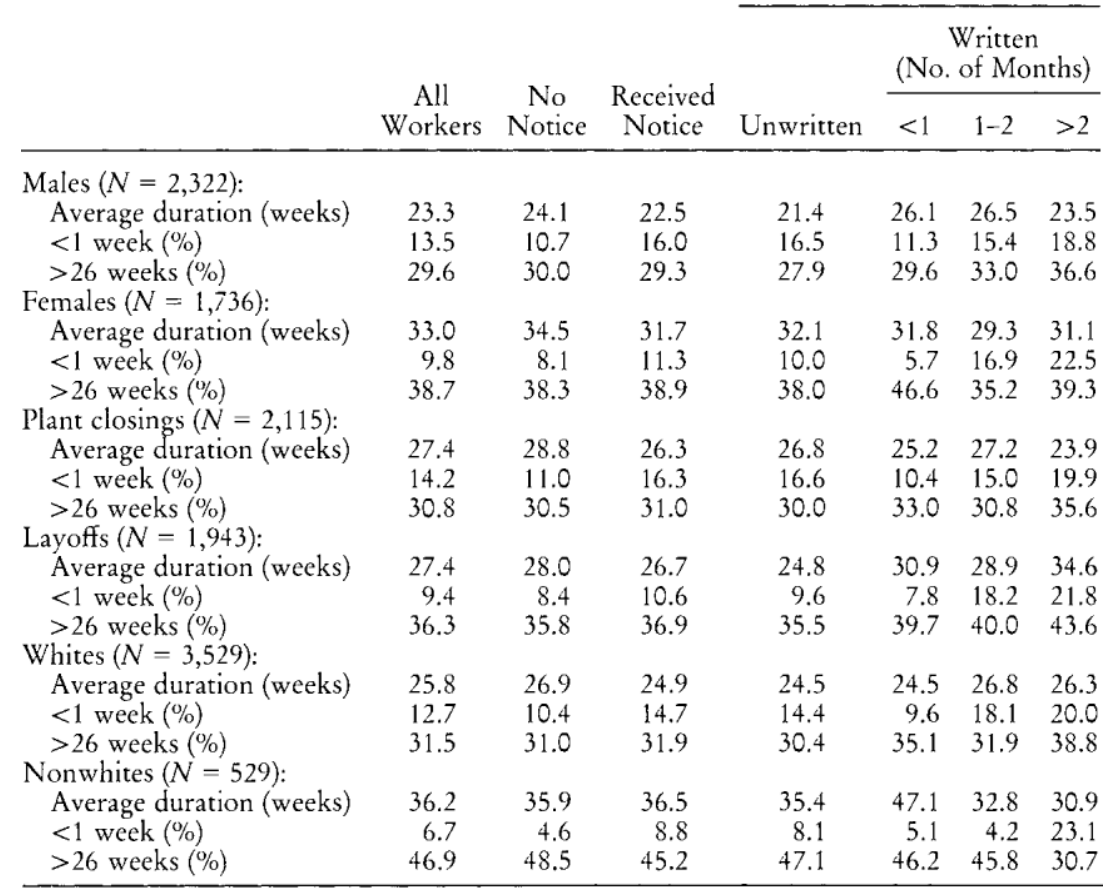

NOTE.-Duration of joblessness is calculated as in table 2.

$$
h(t)=\frac{f(t)}{1-F(t)} .
$$

Taking the integral of (2), the probability that search duration exceeds $T$ periods is

$$
1-F(T)=\exp -\int_{0}^{T} h(v) d v=\exp [-H(T)]
$$

where $H(\cdot)$ is the integral of the hazard function. Lower hazard rates are therefore associated with longer durations of search.

The reduction in joblessness associated with $N$ periods of advance notice is maximized if (1) nonnotified workers are completely surprised by displacements (and so do not begin searching for new employment until the layoff occurs), and (2) individuals initiate search as soon as they are notified and search with the same intensity as if they were already out of work. In 
this case, the probability that the nonemployment duration $(W)$ exceeds $T$ periods, conditional on receiving $N$ periods of advance notice, is

$$
\operatorname{pr}(W>T \mid N)=1-F(T+N)=\exp -H(T+N) ;
$$

the expected duration of joblessness is

$$
E(W \mid N)=[1-F(N)] \int_{N}^{\infty}(t-N) f(t) d t
$$

and the reduction in time out of work, compared to not receiving notice, is

$$
\Delta E(W)=-N[1-F(N)]-\int_{0}^{N} t f(t) d t
$$

The first term in (6) corresponds to an $N$-period reduction for persons experiencing joblessness, despite receiving the early warning; the second shows the decrease for individuals able to avoid joblessness as a result of the announcement.

The actual impact of mandated advance notice will generally be less than the theoretical maximum in (6) for at least two reasons. First, hazard rates are likely to depend on labor market status as well as search durations. In particular, workers may search less intensively or have higher reservation wages prior to displacements than when they are out of work. Second, some persons will anticipate permanent layoffs, even in the absence of notice, and begin searching for new jobs prior to the permanent separation. Similarly, notified individuals may delay their search if they continue to believe there is some probability that the displacement will be forestalled, even after the firm's announcement. In the extreme case, prenotification would have no effect on joblessness.

These concerns do not necessarily present serious problems for empirical investigation. In the simplest model,

$$
W=X \alpha_{1}+N \alpha_{2}+\varepsilon,
$$

with $W$ the measure of duration, $X$ a vector of covariates, $N$ a dummy variable indicating advance notice, and $\varepsilon$ a white noise disturbance; the impact of early notice is measured by $\hat{\alpha}_{2}$. Two potential problems deserve attention, however, when considering the results of prior research.

First, information on prenotification has been previously limited to a general question asking whether displaced workers expected their jobs to end. Affirmative answers to this inquiry are unlikely to indicate the same subjective probabilities of displacements as would have existed if formal 
notice had been received. For instance, one logical rule would be to respond that the termination was expected (unexpected) if the subjective probability is greater (less) than $50 \%$, over a specified time period. If mandated formal notice would raise this probability closer to one, estimates of the effects of broadly defined advance warning would understate the gains to mandatory prenotification. Newly available data on formal notice, from the 1988 DWS, can be used to solve this problem.

A second, more vexing, issue is that the expected error terms of notified and nonnotified workers may be unequal when firms choose whether or not to provide advance notice (i.e., $E(\varepsilon \mid N=0) \neq E(\varepsilon \mid N=1)$ ). This can result in the effects of prenotification being either under- or overestimated. Further discussion of endogeneity bias is deferred until Section VII.

\section{Reduced-Form Estimates}

This section replicates previous reduced-form estimates, examining how advance notice influences the expected duration of postdisplacement joblessness and the probability that workers begin new employment within 1 week of leaving the predisplacement position. Two improvements on earlier analyses are also incorporated. First, greater specificity is included on the type of advance notice. Second, a model is estimated that allows for full interactions between prenotification and the nonnotification covariates. Throughout the remainder of this article, the sample is restricted to persons displaced between 1983 and 1985 (at least 2 years before the survey date). Excluding individuals who lost jobs in 1986 and 1987 reduces the probability that respondents return to their old employers, after the survey date, and eliminates spells that are right-censored at short durations.

\section{A. Econometric Issues}

The DWS top-codes weeks of postdisplacement joblessness (WKSOUT) at 99 weeks. Duration models are well suited to deal with right-censoring and have frequently been used to analyze the determinants of nonemployment durations. In this section, the accelerated failure time (AFT) model,

and

$$
\left.\begin{array}{l}
W=\exp (Z \beta) W_{0}^{\sigma} \\
\ln W=Z \beta+\sigma \mu,
\end{array}\right\}
$$

is estimated. ${ }^{15}$ In equation (8), $Z$ is a vector of individual, geographic, and

${ }^{15}$ Individuals finding new positions in less than 1 week are assumed to be out of work for 0.5 weeks. A number of researchers (e.g., Ehrenberg and Jakubson 1988; Addison and Portugal 1989; and Kletzer 1989) exclude this group of workers. 
job characteristics, $\mu$ is an error term with density $f(\cdot), W_{0}=\exp (\mu)$, and $\sigma$ is a scale parameter. The vector $Z$ includes four dummy variables pertaining to advance notice. These respectively indicate whether the individual expected the displacement in the absence of formal notification (UNWRIT) or received written notice of less than 1 month (WRIT1), 1-2 months (WRIT2), or more than 2 months (WRIT3).

The survivor function for the $i$ th individual is

$$
S_{i}(W)=S_{0}\left[W \exp \left(-Z_{i} \beta\right)\right]
$$

which implies that the log of expected durations is linear in the covariates and the effect of the latter are to rescale time. The error term is assumed to have a generalized gamma distribution. This two-parameter distribution nests the exponential, Weibull, lognormal, gamma, and chi-square distributions, among others. ${ }^{16}$ The log-likelihood function is specified by

$$
L=\sum_{i=1}^{n} c_{i}\left[\ln f\left(\mu_{i} ; k\right)-\ln \sigma\right]+\sum_{i=1}^{n}\left(1-c_{i}\right) \ln F\left(\mu_{i} ; k\right),
$$

where $k$ is the shape parameter of the generalized gamma and $c_{i}=0$ (1) for censored (uncensored) observations.

The relationship between advance notice and the probability of avoiding joblessness is obtained from maximum-likelihood estimates of the probit model:

$$
\mathrm{AVOID}=Z \beta+\mu
$$

where AVOID is a dummy variable equal to one (zero) if WKSOUT is less than (at least) 1 week. ${ }^{17}$ Positive probit coefficients therefore imply increased probabilities of avoiding joblessness.

The effect of prenotification may differ across population groups. To

This will bias upward the notification coefficient if advance notice increases the probability of immediate reemployment but has little effect on durations for those with positive joblessness. This occurs because exclusion of the shortest spells will be more pronounced for notified than for nonnotified workers, with no corresponding effect on the longer nonemployment experiences. In preliminary work, the accelerated failure time model was also estimated for the subsample with positive joblessness, with the expected outcome that the advance notice coefficient increased in size.

${ }^{16}$ The use of generalized gamma distributions in accelerated failure time models is discussed extensively by Addison and Portugal (1987b).

${ }^{17}$ Individuals can avoid joblessness either by finding new jobs prior to the date of displacement, but remaining in the predisplacement position until the layoff occurs, or by departing the old employment as soon as the new job is obtained. 
examine this possibility, two alternative specifications of the probit and AFT models were estimated. The first is the conventional intercept-only model:

$$
Z \beta=X \beta_{0}+N \beta_{1}
$$

where $N$ includes the advance notice variables and $X$ the nonnotification covariates. The second model allows for full interactions between $N$ and $X$ (including the intercept), as defined by

$$
Z \beta=X \beta_{0}+N \cdot X\left(\beta_{1}-\beta_{0}\right),
$$

where the estimated interaction coefficients indicate the differential effect of prenotification on workers with the specified individual, firm, or geographic characteristics.

\section{B. Intercept-only Results}

Table 4 displays probit and AFT coefficients for reduced-form models where advance notice is assumed to affect only the regression intercept. Nonemployment durations are relatively lengthy for females, nonwhites, persons residing in depressed local labor markets or working in slowgrowing industries, and those displaced as the result of partial layoffs. ${ }^{18}$ Heads of households and individuals receiving positive predisplacement wage residuals obtain new employment relatively quickly. The latter result is somewhat unexpected, given that reservation wages are generally thought to increase with previous earnings. ${ }^{19}$

Displaced workers in multiple-earner households surprisingly obtain new positions faster than those providing sole financial support. Conversely, reemployment slows as family size (the number of children) increases. Industry and occupation unionization rates are never statistically significant; however, there is some evidence that residents of right-to-work states become reemployed relatively rapidly. Nonemployment durations may also be slightly longer for UI-eligible individuals than for their counterparts, although this effect is imprecisely measured.

Informally notified workers are more likely to avoid joblessness and have shorter nonemployment durations than counterparts who are surprised by displacements. These differences are statistically significant and quite large. For instance, evaluating nonnotification covariates at their sample means, individuals obtaining informal notice were almost twice as

${ }^{18}$ Similar results have been obtained by Podgursky and Swaim (1987) and Ehrenberg and Jakubson (1988) using the 1984 DWS. Relatively rapid reemployment following plant closings may result from the low associated probabilities of recall.

${ }^{19}$ One explanation is that highly paid workers possess large amounts of marketvalued characteristics. 


\section{Table 4 \\ Regressions Indicating the Effect of Advance Notice and Other Covariates on the Probability of Avoiding and Duration of Postdisplacement Joblessness}

\begin{tabular}{|c|c|c|c|c|c|}
\hline \multirow[b]{2}{*}{ Regressor } & \multicolumn{2}{|c|}{ Dependent Variable } & \multirow[b]{2}{*}{ Regressor } & \multicolumn{2}{|c|}{ Dependent Variable } \\
\hline & $\begin{array}{c}\text { AVOID } \\
(1)\end{array}$ & $\begin{array}{l}\text { WKSOUT } \\
\text { (2) }\end{array}$ & & $\begin{array}{l}\text { AVOID } \\
\text { (1) }\end{array}$ & $\begin{array}{l}\text { WKSOU' } \\
\text { (2) }\end{array}$ \\
\hline EXP & $\begin{array}{r}-.016 \\
(.87)\end{array}$ & $\begin{array}{r}.026 \\
(1.35)\end{array}$ & CLOSING & $\begin{array}{r}.115 \\
(1.32)\end{array}$ & $\begin{array}{l}-.248 \\
(2.84)\end{array}$ \\
\hline EXPSQ & $\begin{array}{l}2.3 \mathrm{E}-4 \\
(.55)\end{array}$ & $\begin{array}{l}5.9 \mathrm{E}-5 \\
(.14)\end{array}$ & RESID & $\begin{array}{r}.223 \\
(2.31)\end{array}$ & $\begin{array}{l}-.130 \\
(1.33)\end{array}$ \\
\hline EDUC & $\begin{array}{r}-.079 \\
(.76)\end{array}$ & $\begin{array}{c}.006 \\
(.06)\end{array}$ & STEUNION & $\begin{array}{l}3.5 \mathrm{E}-4 \\
(.04)\end{array}$ & $\begin{array}{l}-.010 \\
(1.34)\end{array}$ \\
\hline EDUCSQ & $\begin{array}{l}4.9 \mathrm{E}-3 \\
(1.23)\end{array}$ & $\begin{array}{r}-.001 \\
(.35)\end{array}$ & RTWORK & $\begin{array}{r}-.047 \\
(.40)\end{array}$ & $\begin{array}{l}-.260 \\
(2.20)\end{array}$ \\
\hline TENURE & $\begin{array}{r}.043 \\
(1.98)\end{array}$ & $\begin{array}{l}.017 \\
(.78)\end{array}$ & URATE & $\begin{array}{r}.045 \\
(1.04)\end{array}$ & $\begin{array}{c}-.019 \\
(.42)\end{array}$ \\
\hline TENSQ & $\begin{array}{c}-1.3 \mathrm{E}-3 \\
(1.70)\end{array}$ & $\begin{array}{l}5.3 \mathrm{E}-4 \\
(.71)\end{array}$ & AREARATE & $\begin{array}{c}-.014 \\
(.66)\end{array}$ & $\begin{array}{r}.102 \\
(4.80)\end{array}$ \\
\hline MARRIED & $\begin{array}{l}.112 \\
(.91)\end{array}$ & $\begin{array}{l}.047 \\
(.40)\end{array}$ & INDCHG & $\begin{array}{l}.018 \\
(.82)\end{array}$ & $\begin{array}{l}-.050 \\
(2.29)\end{array}$ \\
\hline HEAD & $\begin{array}{r}.251 \\
(1.99)\end{array}$ & $\begin{array}{l}-.733 \\
(6.18)\end{array}$ & OCCRATE & $\begin{array}{c}-3.7 \mathrm{E}-3 \\
(.19)\end{array}$ & $\begin{array}{l}.008 \\
(.43)\end{array}$ \\
\hline FEMALE & $\begin{array}{l}-.295 \\
(2.46)\end{array}$ & $\begin{array}{r}.403 \\
(3.56)\end{array}$ & INDUNION & $\begin{array}{c}-3.5 \mathrm{E}-3 \\
(.77)\end{array}$ & $\begin{array}{c}-.002 \\
(.43)\end{array}$ \\
\hline BLACK & $\begin{array}{l}-.470 \\
(2.63)\end{array}$ & $\begin{array}{r}.643 \\
(4.39)\end{array}$ & OCCUNION & $\begin{array}{c}-4.2 \mathrm{E}-3 \\
(.98)\end{array}$ & $\begin{array}{l}.003 \\
(.63)\end{array}$ \\
\hline OTHRACE & $\begin{array}{l}-.701 \\
(2.10)\end{array}$ & $\begin{array}{r}.991 \\
(4.11)\end{array}$ & UIPROB & $\begin{array}{l}-.404 \\
(1.25)\end{array}$ & $\begin{array}{l}.187 \\
(.56)\end{array}$ \\
\hline NUMCHILD & $\begin{array}{l}-.053 \\
(1.37)\end{array}$ & $\begin{array}{r}.157 \\
(4.28)\end{array}$ & UNWRIT & $\begin{array}{l}-.311 \\
(3.46)\end{array}$ & $\begin{array}{l}-.164 \\
(1.81)\end{array}$ \\
\hline NUMEARN & $\begin{array}{l}.100 \\
(1.94)\end{array}$ & $\begin{array}{l}-.365 \\
(7.13)\end{array}$ & WRIT1 & $\begin{array}{r}-.169 \\
(.92)\end{array}$ & $\begin{array}{l}.323 \\
(1.82)\end{array}$ \\
\hline PRTPREV & $\begin{array}{r}.382 \\
(2.13)\end{array}$ & $\begin{array}{l}.112 \\
(.58)\end{array}$ & WRIT2 & $\begin{array}{r}-.061 \\
(.32)\end{array}$ & $\begin{array}{l}.239 \\
(1.17)\end{array}$ \\
\hline HINS & $\begin{array}{r}-.055 \\
(.51)\end{array}$ & $\begin{array}{c}-.092 \\
(.87)\end{array}$ & WRIT3 & $\begin{array}{l}-.207 \\
(1.22)\end{array}$ & $\begin{array}{r}.280 \\
(1.38)\end{array}$ \\
\hline
\end{tabular}

NOTE.-Description of regression models: dependent variable AVOID equals one if a worker is out of work less than 1 week and zero if jobless for 1 week or more. Regressions are estimated by maximumlikelihood probit. Dependent variable WKSOUT is the number of weeks of postdisplacement joblessness until the first spell of new employment. Joblessness is set to .5 weeks for individuals out of work less than 1 week. Coefficients are obtained from a gamma-distributed accelerated failure time model. Advance notice dummy variables are equal to one if there is no written notice but received unwritten notice or expected job termination (UNWRIT); if worker received less than 1 month's written advance notice (WRIT1); if worker received between 1 and 2 months' written advance notice (WRIT2); or if worker received more than 2 months' written advance notice (WRIT3). The sample is restricted to persons displaced between 1983 and 1985. Absolute values of asymptotic $t$-statistics are in parentheses.

likely to be out of work less than 1 week $(12.0 \%$ vs. $6.9 \%) .^{20}$ Informal notice was similarly associated with a $15.1 \%$ reduction in predicted spell durations, which corresponded to a decrease of around 4.2 weeks.

Whereas the above results replicate the findings of previous researchers,

${ }^{20}$ These percentages are lower than the corresponding probabilities in tables 2 and 3 because displacements occurring during the more robust economic years 1986 and 1987 have been excluded. 
Table 5

Interaction Effects between Advance Notice and Other Covariates on Postdisplacement Joblessness

\begin{tabular}{|c|c|c|c|c|c|c|}
\hline \multirow[b]{3}{*}{ Regressor } & \multicolumn{6}{|c|}{ Interaction Variable } \\
\hline & \multicolumn{2}{|c|}{$\begin{array}{l}\text { UNWRIT } \\
\text { (1) }\end{array}$} & \multicolumn{2}{|c|}{$\begin{array}{l}\text { WRITTEN } \\
\text { (2) }\end{array}$} & \multicolumn{2}{|c|}{$\begin{array}{l}\text { WRIT3 } \\
\text { (3) }\end{array}$} \\
\hline & AVOID & WKSOUT & AVOID & WKSOUT & AVOID & WKSOUT \\
\hline EXP & $\begin{array}{l}-.063 \\
(1.49)\end{array}$ & $\begin{array}{l}.031 \\
(.75)\end{array}$ & $\begin{array}{l}2.9 \mathrm{E}-3 \\
(.05)\end{array}$ & $\begin{array}{c}-.026 \\
(.45)\end{array}$ & $\begin{array}{l}.060 \\
(.44)\end{array}$ & $\begin{array}{c}-.091 \\
(.82)\end{array}$ \\
\hline EXPSQ & $\begin{array}{l}1.6 \mathrm{E}-3 \\
(1.70)\end{array}$ & $\begin{array}{c}-6.7 \mathrm{E}-4 \\
(.74)\end{array}$ & $\begin{array}{c}-2.7 \mathrm{E}-4 \\
(.19)\end{array}$ & $\begin{array}{l}7.3 \mathrm{E}-4 \\
(.57)\end{array}$ & $\begin{array}{c}-2.6 \mathrm{E}-3 \\
(.81)\end{array}$ & $\begin{array}{l}2.8 \mathrm{E}-3 \\
(1.18)\end{array}$ \\
\hline EDUC & $\begin{array}{l}.166 \\
(.71)\end{array}$ & $\begin{array}{l}-.245 \\
(1.10)\end{array}$ & $\begin{array}{c}-.034 \\
(.07)\end{array}$ & $\begin{array}{l}-.743 \\
(1.70)\end{array}$ & $\begin{array}{l}.717 \\
(.38)\end{array}$ & $\begin{array}{c}-.748 \\
(.77)\end{array}$ \\
\hline EDUCSQ & $\begin{array}{c}-5.5 \mathrm{E}-3 \\
(.60)\end{array}$ & $\begin{array}{l}9.8 \mathrm{E}-3 \\
(1.12)\end{array}$ & $\begin{array}{l}2.7 \mathrm{E}-3 \\
(.16)\end{array}$ & $\begin{array}{l}.026 \\
(.61)\end{array}$ & $\begin{array}{c}-.023 \\
(.37)\end{array}$ & $\begin{array}{l}.031 \\
(.91)\end{array}$ \\
\hline TENURE & $\begin{array}{c}.072 \\
(1.43)\end{array}$ & $\begin{array}{l}-.091 \\
(1.91)\end{array}$ & $\begin{array}{l}.061 \\
(.90)\end{array}$ & $\begin{array}{c}-.058 \\
(.92)\end{array}$ & $\begin{array}{r}.203 \\
(1.43)\end{array}$ & $\begin{array}{l}-.122 \\
(1.09)\end{array}$ \\
\hline TENSQ & $\begin{array}{l}-2.5 \mathrm{E}-3 \\
(1.46)\end{array}$ & $\begin{array}{l}2.5 \mathrm{E}-3 \\
(1.49)\end{array}$ & $\begin{array}{c}-1.8 \mathrm{E}-3 \\
(.78)\end{array}$ & $\begin{array}{l}1.9 \mathrm{E}-3 \\
(.92)\end{array}$ & $\begin{array}{c}-3.2 \mathrm{E}-3 \\
(.75)\end{array}$ & $\begin{array}{l}2.5 \mathrm{E}-3 \\
(.78)\end{array}$ \\
\hline MARRIED & $\begin{array}{l}-.444 \\
(1.49)\end{array}$ & $\begin{array}{r}.359 \\
(1.37)\end{array}$ & $\begin{array}{c}-.214 \\
(.59)\end{array}$ & $\begin{array}{l}-.404 \\
(1.20)\end{array}$ & $\begin{array}{r}.434 \\
(.47)\end{array}$ & $\begin{array}{r}-.133 \\
(.05)\end{array}$ \\
\hline HEAD & $\begin{array}{l}-.479 \\
(1.62)\end{array}$ & $\begin{array}{r}.294 \\
(1.15)\end{array}$ & $\begin{array}{r}-.135 \\
(.31)\end{array}$ & $\begin{array}{l}-.875 \\
(2.32)\end{array}$ & $\begin{array}{l}1.312 \\
(1.09)\end{array}$ & $\begin{array}{c}-1.320 \\
(1.67)\end{array}$ \\
\hline FEMALE & $\begin{array}{l}-.699 \\
(2.51)\end{array}$ & $\begin{array}{r}.349 \\
(1.43)\end{array}$ & $\begin{array}{c}-.219 \\
(.54)\end{array}$ & $\begin{array}{r}-.260 \\
(.72)\end{array}$ & $\begin{array}{l}1.708 \\
(1.47)\end{array}$ & $\begin{array}{l}-.754 \\
(1.09)\end{array}$ \\
\hline BLACK & $\begin{array}{r}.739 \\
(1.51)\end{array}$ & $\begin{array}{l}.102 \\
(.32)\end{array}$ & $\begin{array}{r}.618 \\
(1.02)\end{array}$ & $\begin{array}{c}-.373 \\
(.85)\end{array}$ & $\begin{array}{r}2.029 \\
(1.50)\end{array}$ & $\begin{array}{c}-2.314 \\
(2.22)\end{array}$ \\
\hline OTHRACE & $\begin{array}{r}-2.025 \\
(1.08)\end{array}$ & $\begin{array}{c}-.369 \\
(.64)\end{array}$ & $\begin{array}{l}.206 \\
(.28)\end{array}$ & $\begin{array}{c}-.610 \\
(.97)\end{array}$ & $\begin{array}{l}.417 \\
(.06)\end{array}$ & $\begin{array}{c}-3.150 \\
(2.25)\end{array}$ \\
\hline NUMCHILD & $\begin{array}{r}.123 \\
(1.38)\end{array}$ & $\begin{array}{l}-.171 \\
(2.13)\end{array}$ & $\begin{array}{c}.211 \\
(1.77)\end{array}$ & $\begin{array}{c}-.103 \\
(.89)\end{array}$ & $\begin{array}{r}.385 \\
(1.34)\end{array}$ & $\begin{array}{r}-.020 \\
(.09)\end{array}$ \\
\hline NUMEARN & $\begin{array}{c}.148 \\
(1.24)\end{array}$ & $\begin{array}{c}-.102 \\
(.92)\end{array}$ & $\begin{array}{l}.158 \\
(1.01)\end{array}$ & $\begin{array}{c}-.129 \\
(.85)\end{array}$ & $\begin{array}{r}-.287 \\
(.85)\end{array}$ & $\begin{array}{l}-.275 \\
(1.04)\end{array}$ \\
\hline PRTPREV & $\begin{array}{l}-.856 \\
(2.10)\end{array}$ & $\begin{array}{c}.419 \\
(1.02)\end{array}$ & $\begin{array}{r}-.444 \\
(.81)\end{array}$ & $\begin{array}{c}-6.4 \mathrm{E}-3 \\
(.01)\end{array}$ & $\begin{array}{l}.893 \\
(.69)\end{array}$ & $\begin{array}{c}-.886 \\
(.82)\end{array}$ \\
\hline HINS & $\begin{array}{c}-.016 \\
(.07)\end{array}$ & $\begin{array}{r}.365 \\
(1.59)\end{array}$ & $\begin{array}{l}2.8 \mathrm{E}-3 \\
(.01)\end{array}$ & $\begin{array}{l}.088 \\
(.26)\end{array}$ & $\begin{array}{l}1.027 \\
(.90)\end{array}$ & $\begin{array}{l}-.491 \\
(0.56)\end{array}$ \\
\hline
\end{tabular}

estimates on the relationship between written notice and postdisplacement joblessness are new and strikingly different. There is some indication that formal announcements received well in advance of permanent layoffs increase the ability of displaced workers to avoid joblessness. Although the probit coefficient on WRIT3 did not quite reach statistical significance; the point estimate indicated that receipt of more than 60 days' written notice raised the predicted probability of experiencing less than a week of nonemployment from $6.9 \%$ to $10.1 \%$. The corresponding AFT coefficient was positive, however, which implies that there is no corresponding reduction in average durations. ${ }^{21}$

${ }^{21}$ Swaim and Podgursky (1990) and Portugal and Addison (1989) have recently argued that conventional accelerated failure time models understate the reduction 
Table 5 (Continued)

\begin{tabular}{|c|c|c|c|c|c|c|}
\hline \multirow[b]{3}{*}{ Regressor } & \multicolumn{6}{|c|}{ Interaction Variable } \\
\hline & \multicolumn{2}{|c|}{$\begin{array}{l}\text { UNWRIT } \\
\text { (1) }\end{array}$} & \multicolumn{2}{|c|}{$\begin{array}{l}\text { WRITTEN } \\
(2)\end{array}$} & \multicolumn{2}{|c|}{$\begin{array}{c}\text { WRIT3 } \\
(3)\end{array}$} \\
\hline & AVOID & WKSOUT & AVOID & WKSOUT & AVOID & WKSOUT \\
\hline CLOSING & $\begin{array}{c}-.165 \\
(84)\end{array}$ & $\begin{array}{r}.296 \\
(1.57)\end{array}$ & $\begin{array}{l}1.7 \mathrm{E}-3 \\
(01)\end{array}$ & $\begin{array}{r}-.170 \\
(65)\end{array}$ & $\begin{array}{r}.452 \\
(71)\end{array}$ & $\begin{array}{r}-.014 \\
(.03)\end{array}$ \\
\hline RESID & $\begin{array}{c}-.111 \\
(.51)\end{array}$ & $\begin{array}{l}-.261 \\
(1.25)\end{array}$ & $\begin{array}{l}4.5 \mathrm{E}-3 \\
(.01)\end{array}$ & $\begin{array}{l}-.343 \\
(1.09)\end{array}$ & $\begin{array}{c}-1.403 \\
(1.77)\end{array}$ & $\begin{array}{r}-.084 \\
(.13)\end{array}$ \\
\hline STEUNION & $\begin{array}{l}1.6 \mathrm{E}-3 \\
(.09)\end{array}$ & $\begin{array}{r}-.017 \\
(.98)\end{array}$ & $\begin{array}{l}.018 \\
(.76)\end{array}$ & $\begin{array}{l}5.4 \mathrm{E}-3 \\
(.24)\end{array}$ & $\begin{array}{c}-1.1 \mathrm{E}-3 \\
(.03)\end{array}$ & $\begin{array}{l}.023 \\
(.62)\end{array}$ \\
\hline RTWORK & $\begin{array}{l}0.224 \\
(.83)\end{array}$ & $\begin{array}{r}-.023 \\
(.09)\end{array}$ & $\begin{array}{l}.342 \\
(.92)\end{array}$ & $\begin{array}{c}-.226 \\
(.63)\end{array}$ & $\begin{array}{c}-.012 \\
(.01)\end{array}$ & $\begin{array}{l}.371 \\
(.53)\end{array}$ \\
\hline URATE & $\begin{array}{r}.101 \\
(1.01)\end{array}$ & $\begin{array}{l}-.171 \\
(1.77)\end{array}$ & $\begin{array}{l}-.159 \\
(1.20)\end{array}$ & $\begin{array}{l}.094 \\
(.73)\end{array}$ & $\begin{array}{l}-.282 \\
(1.01)\end{array}$ & $\begin{array}{l}-.392 \\
(1.64)\end{array}$ \\
\hline AREARATE & $\begin{array}{l}.046 \\
(.94)\end{array}$ & $\begin{array}{l}3.0 \mathrm{E}-3 \\
(.07)\end{array}$ & $\begin{array}{c}.116 \\
(1.81)\end{array}$ & $\begin{array}{l}-.194 \\
(3.04)\end{array}$ & $\begin{array}{r}.399 \\
(2.38)\end{array}$ & $\begin{array}{l}-.378 \\
(3.49)\end{array}$ \\
\hline INDCHG & $\begin{array}{r}.091 \\
(1.86)\end{array}$ & $\begin{array}{r}-.021 \\
(.44)\end{array}$ & $\begin{array}{l}.059 \\
(.87)\end{array}$ & $\begin{array}{l}.113 \\
(1.67)\end{array}$ & $\begin{array}{l}.038 \\
(.21)\end{array}$ & $\begin{array}{l}.153 \\
(1.15)\end{array}$ \\
\hline OCCRATE & $\begin{array}{l}-.087 \\
(1.97)\end{array}$ & $\begin{array}{l}.106 \\
(2.54)\end{array}$ & $\begin{array}{c}-.013 \\
(.24)\end{array}$ & $\begin{array}{r}-.013 \\
(.23)\end{array}$ & $\begin{array}{l}-.155 \\
(1.20)\end{array}$ & $\begin{array}{r}.270 \\
(2.23)\end{array}$ \\
\hline INDUNION & $\begin{array}{r}.012 \\
(1.18)\end{array}$ & $\begin{array}{l}.011 \\
(1.10)\end{array}$ & $\begin{array}{l}6.9 \mathrm{E}-3 \\
(.48)\end{array}$ & $\begin{array}{c}-.012 \\
(.84)\end{array}$ & $\begin{array}{l}3.9 \mathrm{E}-3 \\
(.11)\end{array}$ & $\begin{array}{l}.016 \\
(.60)\end{array}$ \\
\hline OCCUNION & $\begin{array}{c}-7.1 \mathrm{E}-3 \\
(.74)\end{array}$ & $\begin{array}{l}-.011 \\
(1.15)\end{array}$ & $\begin{array}{c}-.019 \\
(1.39)\end{array}$ & $\begin{array}{c}.026 \\
(1.96)\end{array}$ & $\begin{array}{l}-.059 \\
(1.56)\end{array}$ & $\begin{array}{c}-6.1 \mathrm{E}-3 \\
(.21)\end{array}$ \\
\hline UIPROB & $\begin{array}{c}-1.409 \\
(1.89)\end{array}$ & $\begin{array}{l}.492 \\
(.68)\end{array}$ & $\begin{array}{r}-.447 \\
(.44)\end{array}$ & $\begin{array}{r}-.415 \\
(.41)\end{array}$ & $\begin{array}{r}-2.205 \\
(.99)\end{array}$ & $\begin{array}{c}.974 \\
(.54)\end{array}$ \\
\hline
\end{tabular}

NOTE.-The equations estimated are of the form $W=X \beta_{0}+X \cdot N\left(\beta_{1}-\beta_{0}\right)+\mu$. Coefficients displayed are for the interaction terms $X \cdot N$. Absolute values of symptotic $t$-statistics are in parentheses. The sample is restricted to persons displaced between 1983 and 1985. Advance notice dummy variables equal one if there is no written notice but received unwritten notice or expected job termination (UNWRIT); if worker received written advance notice of any duration (WRITTEN); or if worker received more than 2 months' written advance notice (WRIT3). Persons receiving written notice are excluded from the model with interactions on informal notice; informally notified individuals are left out when the interactions of written notice are considered; persons obtaining informal notice or less thian 2 months' written warning are deleted when interactions on formal notice of at least 2 months are considered.

The negative probit and positive AFT coefficients on WRIT1 and WRIT2 indicate that short periods of formal advance warning, if anything, are associated with longer nonemployment durations. It is particularly striking that persons receiving written announcements less than 1 month before the layoff date were predicted to be jobless $38 \%$ longer than their nonnotified counterparts. This result barely misses being statistically significant.22

in joblessness associated with advance notice because they do not adequately account for predisplacement search. Section VII of this article suggests that they also fail to take important endogeneity biases into account.

22. The relationship between advance notice and longer-term employment stability was also examined by estimating a probit model of the probability of working for pay in January 1988. Coefficients on UNWRIT, WRIT1, and WRIT3 were positive 
Since written notification generally provides more detail about the date and nature of impending displacements than informal notice, it is implausible that the latter speeds reemployment while the former retards it. A more probable explanation is that the reduced-form regression model is misspecified because it fails to account for the potential endogeneity of advance notice. This possibility is addressed in Section VII.

\section{Advance Notice Interactions}

Coefficients on the interactions between advance notice and other covariates, obtained from the regression model specified by equations (11b) and (8) or (10), are shown in table 5. Three types of prenotification are considered: UNWRIT and WRIT3 are defined as before, while WRITTEN is a new dummy variable that indicates formal notice of any duration (i.e., WRITTEN equals one if WRIT1, WRIT2, or WRIT3 is equal to one).

Important variations are observed in the effects of advance notification. Particularly noteworthy are the large reductions in joblessness associated with lengthy periods of formal notice for household heads, women, nonwhites, and displaced workers living in areas with high unemployment. Substantial benefits were also obtained by persons departing jobs in occupations with low unemployment and possibly in rapidly growing industries (see table 5, cols. 5 and 6).

Comparing the results in columns (1) and (2) to corresponding coefficients in columns (5) and (6) in table 5 provides further evidence that the measured impact of informal notice differs markedly from that of written prenotification of the type now mandated by law. For instance, unwritten warning is of relatively limited value to heads of households, women, and minorities, whereas exactly the opposite is true for lengthy written notice. The large beneficial effect of formal announcements for workers in depressed local labor markets is not replicated when considering informal notice, but large decreases in joblessness for notified part-time workers are observed in the latter case. Signs on the interaction coefficients are also reversed for marital status, health insurance, plant closings, state union densities, and residence in right-to-work states. These findings further qualify the usefulness of previous research using broad definitions of advance notice that include expectations of job loss in the absence of written announcements.

\section{Summary}

Informal notice is correlated with substantial reductions in postdis placement joblessness. This finding is consistent with earlier research utiwhile that on WRIT2 was negative. The predicted effect was fairly small in all cases, however, and the t-statistic never exceeded 0.71 . This suggests that prior notification either has no effect or slightly improves future employment prospects. 
lizing broad definitions of prenotification. The results are new and dramatically different, however, when attention is restricted to the written notice now mandated by law. Formal announcements received at least 2 months before permanent layoffs were associated with smaller increases in the likelihood of avoiding joblessness and with no reductions in the average durations. More substantial benefits were observed for heads of households, women, nonwhites, and persons residing in depressed local labor markets. Shorter periods of written notice neither reduced durations nor increased probabilities of moving directly into new jobs. The point estimates actually imply longer joblessness, which may indicate the failure to account for endogeneity in the provision of advance notice. The results also suggest serious shortcomings in previous analyses that have relied on broad definitions of prenotification.

\section{Endogenous Advance Notice}

Prior to 1989, only three states (Maine, Wisconsin, and Hawaii) required employers to provide advance notification of impending terminations. Reduced-form models estimated using the DWS therefore indicate the relationship between voluntarily provided advance notice and postdisplacement joblessness. If firms warn employees on a nonrandom basis, these estimates may poorly indicate the impact of mandated prenotification.

Endogeneity bias could cause the prenotification effect to be either underor overstated. If firms more frequently notify workers in depressed local labor markets rather than in healthy ones (in order to minimize premature quits), then early warning is likely to be associated with small reductions or even increases in joblessness. This occurs because new employment is especially difficult to obtain when local unemployment rates are elevated. Conversely, if individuals with a special aversion to unemployment both work for employers providing notice and are less selective in the positions they will accept, then, following terminations, advance notice will be negatively correlated with postdisplacement joblessness, even if there is no "true" notification effect.23

Two additional factors are likely to cause the benefits of informal notice to be overestimated. First, workers who are particularly well informed about labor market conditions will both anticipate job losses and rapidly find new employment more often than their counterparts who are less knowledgeable. Second, ex post rationalization may lead persons with satisfactory reemployment experiences to respond that they anticipated

23. Ehrenberg and Jakubson (1988) provide the most extensive analysis to date of the endogeneity problem but are unable to resolve it with any satisfaction. They conclude, "We are skeptical of our ability to use the estimates obtained here to control for the endogeneity of advance notice in the duration of nonemployment and postdisplacement wage equations" (p. 45). 
displacements, while those with greater difficulties report being surprised by involuntary terminations.

Conversely, an artifact of the DWS questionnaire procedures may result in the gains from formal notice being understated. The problem occurs because the survey fails to ascertain whether job terminations are anticipated prior to the receipt of written announcements. To the extent that they are, formal notice is likely to be disproportionately obtained by workers with low reemployment probabilities, as persons with better employment alternatives are more likely to leave the firm prior to the time at which the written notice is provided. A more detailed discussion of this sorting bias is included in the Appendix.

\section{A. Testing for Endogeneity}

The search model suggests that prenotification should either speed reemployment or have no effect on expected durations. The former result occurs if early notice increases the time or intensity of predisplacement search, the latter if advance warning has no effect on search behavior. There is no theoretical reason why advance notice should ever delay reemployment. Evidence that early announcements are associated with increased joblessness therefore provides a clear indication that they are disproportionately provided to workers with low hazard rates. In this case, reducedform estimates understate the benefits of prenotification.

Section VI B showed that formally notified individuals have relatively lengthy nonemployment spells, suggesting the importance of the justmentioned endogeneity bias. Confirming evidence is obtained by examining the cumulative reemployment probabilities of notified and nonnotified workers. The probability that an individual with observable characteristics $X$ and notification status $N$ becomes reemployed within a maximum of $t$ periods is $F(t / X, N)$. The search model implies that $F(t / X, N=1)$ will be at least as great as $F(t / X, N=0)$, for any given $t$, unless notified workers possess unobserved characteristics associated with delayed reemployment.

Cumulative reemployment probabilities (hereafter simply denoted as "reemployment probabilities") through durations of 18 weeks are displayed in table 6 . The first panel shows actual percentages of workers with spells ending within the specified time period. The second panel displays predicted probabilities for a hypothetical worker with personal, job, and geographic characteristics equal to the sample averages. These estimates are obtained from probit models that include the full vector of covariates, with the dependent variable equaling one (zero) if nonemployment is less than or equal to (greater than) the specified number of weeks.

At durations of 2 weeks or more, predicted reemployment probabilities are uniformly lower for workers receiving written notice than for their counterparts surprised by displacements. For instance, the hypothetical worker has a 0.433 probability of ending joblessness within 8 weeks if no 


\section{Table 6}

\section{Probability That Joblessness Ends within Specified Number of Weeks}

\begin{tabular}{|c|c|c|c|c|c|}
\hline \multirow[b]{3}{*}{ No. of Weeks } & \multicolumn{5}{|c|}{ Type of Advance Notice } \\
\hline & \multirow[b]{2}{*}{$\begin{array}{l}\text { No Notice } \\
\text { (1) }\end{array}$} & \multirow{2}{*}{$\begin{array}{l}\text { Unwritten } \\
\text { Notice } \\
\text { (2) }\end{array}$} & \multicolumn{3}{|c|}{$\begin{array}{l}\text { Written Notice } \\
\text { (No. of Months) }\end{array}$} \\
\hline & & & $\begin{array}{l}<1 \\
(3)\end{array}$ & $\begin{array}{l}1-2 \\
(4)\end{array}$ & $\begin{array}{l}>2 \\
(5)\end{array}$ \\
\hline \multicolumn{6}{|c|}{ Sample probabilities: } \\
\hline 0 & .081 & .135 & .085 & .129 & .222 \\
\hline 2 & .217 & .242 & .162 & .200 & .244 \\
\hline 4 & .329 & .341 & .291 & .271 & .322 \\
\hline 6 & .382 & .391 & .385 & .306 & .356 \\
\hline 8 & .451 & .461 & .402 & .376 & .378 \\
\hline 10 & .481 & .485 & .419 & .412 & .422 \\
\hline 12 & .531 & .527 & .462 & .447 & .456 \\
\hline 14 & .545 & .557 & .487 & .482 & .478 \\
\hline 16 & .575 & .586 & .504 & .482 & .500 \\
\hline 18 & .582 & .605 & .521 & .518 & .500 \\
\hline \multicolumn{6}{|c|}{ Predicted probabilities: } \\
\hline 0 & .069 & .120 & .049 & .061 & .101 \\
\hline 2 & .204 & .227 & .142 & .174 & .186 \\
\hline 4 & .306 & .327 & .270 & .249 & .328 \\
\hline 6 & .362 & .380 & .370 & .294 & .338 \\
\hline 8 & .433 & .456 & .392 & .363 & .361 \\
\hline 10 & .464 & .483 & .413 & .404 & .408 \\
\hline 12 & .520 & .529 & .466 & .454 & .450 \\
\hline 14 & .535 & .559 & .478 & .485 & .466 \\
\hline 16 & .570 & .592 & .500 & .486 & .487 \\
\hline 18 & .579 & .611 & .504 & .516 & .471 \\
\hline
\end{tabular}

NOTE.-Predicted probabilities were obtained from probit regressions, with the nonnotification regressors evaluated at the sample means. The sample is restricted to persons displaced between 1983 and 1985 .

notice is provided (see table 6, col. 1). This compares to probabilities of $0.392,0.363$, and 0.361 , respectively, if less than $1,1.2$, or over 2 months' written notice is obtained ( cols. 3.5). Similarly, the predicted probability of reemployment within 18 weeks is 0.579 without prenotification versus $0.504,0.516$, and 0.471 if the respective durations of formal notice are received. 24

Despite the extra time available for search, formally notified workers have longer nonemployment durations than their observably similar counterparts who do not expect displacements. Written announcements are therefore disproportionately received by persons who, controlling for observable characteristics, have low hazard rates. This could result from the previously mentioned sorting process and certainly indicates serious biases in the reduced-form regressions. It is also noteworthy that predicted reemployment probabilities of formally notified workers are always lower than corresponding sample rates. This shows that written announcements are

24. The differences in predicted reemployment rates become even more pronounced beyond 18 weeks. 
obtained by persons with observed characteristics correlated with rapid reemployment and highlights the disparate effects of observed and unobserved heterogeneity.

Informally notified workers have consistently higher reemployment probabilities than their nonnotified peers (see table 6, cols. 1 and 2). This may occur because unwritten notice is systematically provided to persons with high hazard rates. Alternatively, nonemployment durations may be shorter because of the extra search time available to this group.

Analysis of search behavior suggests a way to distinguish these two possibilities. Advance notice reduces spell durations by allowing predisplacement search. The degree to which the early search is helpful can be estimated by calculating the spell duration at which the percentage of reemployed nonnotified workers equals the proportion of notified individuals avoiding joblessness altogether. In other words, find $\tau$ such that $F(\tau \mid X$, $N=0)$ is equal to $F(0 \mid X, N=1)$. If notified and nonnotified workers have similar unobserved characteristics, $F(t+\tau \mid X, N=0)$ would then be expected to approximately equal $F(t \mid X, N=1)$ for any given $t$. Conversely, $F(t \mid X, N=1)$ will be greater (less) than $F(t+\tau \mid X, N=0)$ for positive $t$ if notification is systematically provided to workers with high (low) hazard rates.

Informally notified workers, with sample average characteristics, are predicted to avoid joblessness $12.0 \%$ of the time (see table 6). If no advance warning is received, then the corresponding probability of avoiding joblessness is $6.9 \%$ and that of being out of work for a maximum of 1 week is $14.5 \%$. This implies that $\tau$ is slightly less than 1 week. To the extent that $\tau$ shows the effect of advance warning, this provides the first indication that reduced-form estimates dramatically overstate the beneficial impact of informal notification.

The bias in reduced-form estimates occurs because informal notice is disproportionately obtained by workers with high hazard rates. This is illustrated by comparing $F(t+1 \mid N=0)$ to $F(t \mid N=1)$ for various levels of $t$. Given that reemployment probabilities are greater for nonnotified workers at $t$ equals one than for informally notified workers at $t$ equals zero $(0.145$ vs. 0.120$)$, they would also be expected to have higher rates of reemployment at positive values of $t$ if the two groups have the same hazard distributions. Conversely, greater reemployment propensities for the informally notified indicate that this type of notice is systematically obtained by persons with high hazard rates.

Table 7 shows predicted reemployment probabilities at $t$ weeks for informally notified workers and at $t+1$ weeks for individuals without notice. At $t$ equals 4 weeks, rates of reemployment are 0.9 percentage points $(2.8 \%)$ higher for the former group than for the latter. The difference exceeds one percentage point at longer durations (with the exception of $t=23$ weeks, where the disparity is 0.6 percentage points), and there is some evidence that the dispersion of reemployment experiences becomes more pro- 


$\begin{aligned} & \text { Table } 7 \\ & \text { Predicted Cumulative Reemployment Probabilities }\end{aligned}$
for Nonnotified and Informally Notified
forkers

NOTE.--Predicted probabilities are obtained from probit regressions, with the nonnotification regressors evaluated at the sample means. The sample is restricted to persons displaced between 1983 and 1985.

nounced for lengthy spells. For instance, the probability that the hypothetical worker's spell ends within 53 weeks is $89.4 \%$ when notice is received. If the termination were unexpected, however, then the corresponding 54-week reemployment probability is only $87.4 \%$. This seemingly small difference is more dramatic when survival rates are considered. Informally notified workers have a $10.6 \%$ probability of remaining jobless beyond 53 weeks, nonnotified counterparts continue to be out of work past 54 weeks $12.6 \%$ of the time. Thus, corresponding survival probabilities are almost $19 \%$ larger for the latter group than for the former. The more rapid reemployment associated with informal notice is therefore at least partially attributable to this type of early warning being systematically obtained by workers with high hazard rates.

\section{B. Endogeneity-corrected Estimates}

This section develops a procedure for calculating endogeneity-corrected estimates of the effect of advance notice. The key assumption made is that prenotification reduces durations by raising the probability of avoiding nonemployment but has no effect on hazard rates once the spell of joblessness begins. This assumption is not entirely realistic. For instance, if individuals engage in systematic search, then both reservation and offer wages will decline with the period of advance notice. The reduction in reservation wages increases hazard rates, while the fall in expected wage offers lowers them. It is therefore not obvious whether prenotification will raise or lower hazard probabilities at given durations of joblessness. The empirical evidence suggests that the fall in expected wage offers dominates, 
with the result that notified workers have lower reemployment hazards. ${ }^{25}$ If so, then the method used in this section will overstate the beneficial effects of advance notice.

The probability that a nonemployment spell ends within $t$ weeks is $F(t$, $X, N)$, where $X$ again indicates individual characteristics and $N$ shows advance notice status. Weekly reemployment hazards are assumed to be independent of advance notice and are defined by $h(t, X)$. Expected spell durations are therefore equal to

$$
E(W \mid X, N)=[1-F(0, X, N)] \sum_{t=1}^{\infty} f(t, X, N) t,
$$

where $f(t, X, N)=h(t, X)[1-F(t-1, X, N)]$ and $F(t, X, N)=$ $F(t-1, X, N)+f(t, X, N)$. Notice that the reemployment density and distribution functions depend on $N$, even though the hazard rate does not (for $t>0$ ).

Advance notice reduces expected joblessness if $F(0 \mid X, N=0)$ is less than $F(0 \mid X, N=1)$. Section VII A indicates that written announcements are systematically provided to workers with low reemployment probabilities, informal warnings to persons with high hazard rates. This suggests that an upper bound on the advance notice effect can be obtained by comparing predicted durations for informally notified workers to those for persons lacking any type of advance notice. A lower bound is provided by comparing the latter group to workers receiving more than 2 months' written notice. ${ }^{26}$

Predicted reemployment probabilities are obtained from probit models, as in Section VII A. Hazard rates are then calculated using the formula $h(t)=[F(t)-F(t-n)] /[1-F(t-n)]$, with $X$ and $N$ suppressed for expositional convenience. One-week hazard rates are estimated for nonemployment durations between 0 and 24 weeks, 5 -week reemployment hazards for spells of between 24 and 94 weeks. In the latter case, individuals are assumed to be reemployed at the midpoint of the 5-week periods. Since joblessness is right-censored at 99 weeks and only two respondents report being out of work between 95 and 98 weeks, hazard rates cannot be directly estimated beyond 94 weeks. At longer durations, 5-week hazard rates are assumed to equal the average predicted 4-week hazard rate for the period spanning durations of 75-94 weeks. ${ }^{27}$

${ }^{25}$ For instance, predicted hazard rates between 0 and 2 weeks are 0.145 for nonnotified workers, 0.122 for informally notified individuals, and 0.095 for persons receiving more than 2 months' written notice (see table 6).

${ }^{26}$ Expected durations, calculated by eq. (12), are longer for persons receiving brief written notice than for those surprised by displacements. This indicates an endogeneity bias that the procedure does not correct for.

${ }^{27}$ It is important to average hazard rates over several periods because of "round off" bias. This is discussed further below. 
Table 8

Predicted Hazard Rates for 1- and 5-Week Intervals

\begin{tabular}{cc|cc}
\hline & $\begin{array}{c}\text { Predicted } \\
\text { Huration (Weeks) }\end{array}$ & $\begin{array}{c}\text { Predicted } \\
\text { Hazard Rate }\end{array}$ \\
\hline 1-week hazard rates: & & Duration (Weeks) & \\
1.0 & .0701 & 21.0 & .1099 \\
2.0 & .0627 & 22.0 & .0240 \\
3.0 & .0502 & 23.0 & .0014 \\
4.0 & .0847 & 24.0 & .0543 \\
5.0 & .0190 & 5 -week hazard rates: & .2249 \\
6.0 & .0620 & 26.5 & .1097 \\
7.0 & .0137 & 31.5 & .0861 \\
8.0 & .0960 & 36.5 & .0734 \\
9.0 & .0202 & 41.5 & .0242 \\
10.0 & .0327 & 46.5 & .4005 \\
11.0 & .0062 & 51.5 & .0584 \\
12.0 & .0869 & 56.5 & .0536 \\
13.0 & .0343 & 61.5 & .0020 \\
14.0 & .0151 & 66.5 & .0132 \\
15.0 & .1308 & 71.5 & .1771 \\
16.0 & .0553 & 76.5 & .0339 \\
17.0 & .0233 & 81.5 & .0130 \\
18.0 & .0094 & 86.5 & .0235 \\
19.0 & .0029 & 91.5 & .0619 \\
20.0 & .0352 & $96.5+$ & \\
\hline
\end{tabular}

NOTE.- Hazard rates are calculated from probit regressions indicating probabilities that duration ends within specified durations, with regressors evaluated at sample means. Hazard rates beyond 92 weeks are calculated as the average of the rates for the preceding four (5-week) periods. The sample is restricted to persons displaced between 1983 and 1985.

Table 8 displays predicted 1 - and 5-week reemployment hazards, evaluated with a nonnotification covariates set equal to the sample means. Hazard probabilities generally decline with spell durations, as is expected if the regressors fail to account for all relevant heterogeneity. For instance, 1 -week hazard rates average 0.0669 between 1 and 4 weeks, 0.0477 between 5 and 8 weeks, and 0.0365 between 9 and 12 weeks. Displaced workers also appear to "round off " reported durations of joblessness. Thus, there is a jump in the hazard rate at 1, 2, 6, 12, and 18 months, as well as at 10, 15 , and 20 weeks. The rise in reemployment hazards in the neighborhood of 26 weeks also suggests the effect of exhausting unemployment insurance benefits.

Nonnotified workers with sample-average characteristics are predicted to avoid nonemployment $6.9 \%$ of the time. This rises to $10.9 \%$ if written announcements are provided more than 2 months before the displacement and $12.0 \%$ if informal notice is received (see table 6). Substituting these values for $\mathrm{F}(01 X, N)$ and the hazard rates in table 8 into equation (12) and solving yields predicted nonemployment durations. They are 29.11 weeks for individuals surprised by displacements, 28.11 weeks for the informally notified, and 28.70 weeks for workers receiving more than 2 
months' written notice.28 This implies that prenotification reduces average postdisplacement joblessness by between 0.41 and 1.00 weeks.

It is instructive to compare these findings to the reduced-form estimates of this and previous research. The model in Section VI B yielded the prediction that informal notice decreases durations by approximately 1 month. This result accords closely with earlier studies examining broad measures of prenotification using the 1984 and 1986 DWS. In contrast, formal notification was associated with longer nonemployment durations. As argued above, these findings fail to correct for important endogeneity biases that occur because informal (formal) notice is predominantly received by persons with high (low) hazard rates. The endogeneity-corrected estimates presented in this section indicate that prenotification reduces nonemployment durations by between 2 days and 1 week. This is only one-eighth to one-fourth as large as the estimate typically obtained by previous researchers.

\section{Summary and Conclusions}

The effect of advance notification on postdisplacement joblessness is analyzed using a new data source that differentiates between written notice and less formal types of early warning. This distinction has been largely ignored in previous research even though informal notification, which includes both verbal announcements and ill-defined "expectations" of impending displacements, is of limited relevance for the current policy debate on the efficacy of legislation mandating specific written notice.

Reduced-form estimates of the effects of formal and informal notice differ dramatically. Workers expecting terminations, in the absence of written notice, have higher probabilities of avoiding nonemployment and shorter spell durations than their nonnotified counterparts. Lengthy formal notice is associated with smaller increases in the likelihood of escaping joblessness altogether and with no decline in the average duration of nonemployment. Written announcements received shortly before the date of displacement neither reduce average durations nor increase the probability of avoiding joblessness.

Reduced-form estimates of the prenotification effect also vary significantly across population subgroups. For instance, durations are relatively short for formally notified household heads, females, nonwhites, and residents of local areas with high unemployment. The same differential effects are not observed when focusing on informal notice, however, which further

28. The need to calculate an infinite sum is avoided by noting that, with constant hazard rates, $h$, the expected remaining spell duration is $1 / \mathrm{h}$. Thus, spells continuing past 92 weeks are expected to last for an additional $16.15(1 / 0.0619) 5$-week periods, or 80.78 weeks. Since respondents specify weeks of joblessness in integer values, there is some ambiguity as to exact spell durations. For this analysis, one-half week was added to all responses. The estimated impact of prenotification is insensitive to this assumption. 
suggests that previous research examining broadly defined advance notification poorly indicates the impact of the formal warnings now mandated by federal legislation.

Reduced-form models also fail to account for the possibility that prenotification is systematically provided to workers with high or low exit rates out of nonemployment. Analysis of cumulative reemployment probabilities indicates that informally (formally) notified individuals possess unobserved characteristics associated with high (low) reemployment hazards. This implies that reduced-form estimates understate (overstate) the beneficial effects of written (unwritten) advance notice.

A technique was developed to correct for this endogeneity of advance notice. The procedure assumes that prenotification raises the probability of avoiding nonemployment altogether but has no effect on hazard rates once the spell of joblessness begins. Using this approach, advance notice is estimated to reduce nonemployment durations by between 2 days and 1 week. This is between one-eighth and one-fourth as large as the typical estimate of previous research.

Future work should attempt to explicitly model the process by which workers become informed about future displacements. Until this is done, it will be unclear to what extent advance notice provides employees with new information. Greater attention also needs to be paid to variability in the effects of prior notification across population subgroups. As shown above, these differences are frequently larger than the average impact. The endogeneity problem likewise deserves more sophisticated analysis. Although prenotification is now mandated by the federal government, the legislation includes numerous, often vaguely specified, exemptions. This ensures that employers will continue to have considerable discretion in deciding whether or not to provide advance notice.

Finally, consideration of the effect of advance warning for subsequent earnings is needed. Recent research suggests that increased postdisplacement joblessness is largely transitory, while the associated wage changes are more permanent (see Topel 1990; Ruhm 1991a). Thus, the main potential benefit of prenotification may be to reduce the earnings losses. One recent study (Ruhm 1991b) indicates that relative wage gains exceeding $10 \%$ are obtained by persons receiving lengthy written notice. These earnings effects, if verified by subsequent research, are substantially larger than the small reductions in joblessness focused on in this analysis.

\section{Appendix}

\section{Written Advance Notice and Sorting Behavior}

To demonstrate potential sorting bias in reports of written advance notice, consider a situation where (1) hazard rates are constant over time; (2) the population consists of two groups with hazard functions $h_{l}(t)=h$, and $h_{2}(t)=\mathrm{h}_{2}$, respectively, where $h,>\mathrm{h}_{2}$ and the shares of 
the two groups are $\lambda$ and $1-\lambda$; (3) informal notice is randomly provided to some fraction of workers at time zero; and (4) at period $S$, formal notice is given to a random fraction of informally notified workers that they will be terminated in $N$ periods, while the remainder of the work force is terminated immediately.

The initial (time 0 ) sample-average hazard rate is

$$
A(S)=\lambda h_{1}+(1-\lambda) h_{2}=\lambda\left(h_{1}-h_{2}\right)+h_{2} .
$$

The sample-hazard rate at the time when formal notice is first received is

$$
B(S)=\frac{\lambda\left[1-F_{1}(S)\right] h_{1}+(1-\lambda)\left[1-F_{2}(S)\right] h_{2}}{\lambda\left[1-F_{1}(S)\right]+(1-\lambda)\left[\left(1-F_{2}(S)\right]\right.} .
$$

It is easy to show that $B(S)<A(S)$ if $h_{1}>h_{2}$. This implies that hazard rates, out of search, are higher for informally notified workers than for formally notified workers. Search duration is not observed in the DWS, however. Instead, information is available on whether workers move directly into new jobs and on hazard rates out of nonemployment. For workers receiving only informal notice, the probability of the former is

$$
\operatorname{pr}(W=0 \mid I)=\lambda F_{1}(S)+(1-\lambda) F_{2}(S)
$$

and of the latter is

$$
b(t \mid I)=B(S+t),
$$

where $I$ is a dummy variable indicating the receipt of informal advance notice and $t$ is the duration of unemployment.

Corresponding probabilities for formally notified workers are

$$
\operatorname{pr}(W=0 \mid F)=\frac{\lambda\left[1-F_{1}(S)\right] F_{1}(N)+(1-\lambda)\left[1-F_{2}(S)\right] F_{2}(N)}{\lambda\left[1-F_{1}(S)\right]+(1-\lambda)\left[1-F_{2}(S)\right]}
$$

and

$$
h(t \mid F)=\frac{\begin{array}{c}
\lambda\left[1-F_{1}(S)\right]\left[1-F_{1}(N+t)\right] h_{1} \\
\lambda\left[1-F_{1}(S)\right]\left[1-F_{1}(N+t)\right] \\
\quad+(1-\lambda)\left[1-F_{2}(S)\right]\left[1-F_{2}(N+t)\right]
\end{array}}{}
$$

where $F$ indicates the receipt of formal notice.

The relationships between (A3) and (A5), and (A4) and (A6), are indeterminant, depending on the relative durations of formal and informal 
notice. If the two types of notice are of approximately equal length, then sorting will result in higher hazard rates and probabilities of avoiding joblessness for informally notified workers. For instance, this is guaranteed if $S$ is equal to $N$.

\section{Description of Variables Used in Analysis, Obtained from CPS-DWS}

Continuous variables:

$\mathrm{EXP}=$ years of potential labor market experience $($ age - education -6$)$

$\mathrm{EXPSQ}=\mathrm{EXP} * \mathrm{EXP}$

EDUC $=$ years of schooling (censored at 17 years)

EDUCSQ $=$ EDUC $*$ EDUC

TENURE $=$ number of years working for the predisplacement employer

TENSQ $=$ TENURE $*$ TENURE

NUMCHILD = number of children under the age of 18

NUMEARN $=$ number of earners $(16+)$ in family

Dummy variables (equal to one if):

MARRIED $=$ married with spouse living in household

HEAD $=$ head of household

FEMALE $=$ female

BLACK $=$ black

OTHRACE = Hispanic, Asian, or other (nonblack) nonwhite

PRTPREV = part-time work (self-defined) in predisplacement job

HINS $=$ included in group health insurance plan in predisplacement job

CLOSING $=$ job terminated due to plant closure or relocation

MANDSTE $=$ worker resides in state with mandatory advance notice legislation

(Maine, Wisconsin, or Hawaii)

VOLSTE $=$ worker resides in state with program to encourage voluntary advance notice (Massachusetts, Michigan, or Maryland).

EXPECT $=$ displacement "expected" or advance notice received

WRITTEN $=$ received written advance notice of displacement

WRITGT1 $=$ received $>1$-month written advance notice of displacement

WRITGT2 $=$ received $>2$-month written advance notice of displacement

Variables obtained from other sources or constructed:

STEUNION = state unionization rate in 1982 (source: U.S. Department of Commerce 1988)

RTWORK = dummy variable indicating residence in "right-to-work" state (source: U.S. Department of Commerce 1988)

URATE = national unemployment rate for the year of displacement

AREARATE $=$ unemployment rate in year of displacement for SMSA of residence (if the worker resides in one of the 50 largest SMSAs) or state unemployment rate otherwise (source: U.S. Department of Labor 1982-88)

INDCHG = average annual growth rate of industry employment (19 industry categories), 1980-86 (source: U.S. Department of Commerce 1988)

OCCRATE = unemployment rate by occupation (12 categories) for 1986 (source: U.S. Department of Commerce 1988)

INDUNION $=$ average unionization rate by industry (19 categories) for 197880 (source: Kokkenlenberg and Sockell 1985)

OCCUNION $=$ average unionization rate by occupation (12 categories) for 1978-80 (source: Kokkenlenberg and Sockell 1985)

RESID = wage residual: obtained from subtracting actual log real wage from predicted value obtained from an earnings regression with controls for indi- 
vidual characteristics and state fixed effects (but not for industry or occupation characteristics)

UIPROB = probability of being eligible for unemployment benefits: obtained from probit regression estimated for persons with $>1$ week of postdisplacement joblessness; regressors include individual characteristics, previous wages, and fixed effects for the year of displacement (4 variables), 48 industries, 44 occupations, and 50 states

Table A1

Binary and Ordered Probit Regressions on the Probability of Receiving Advance Notice

\begin{tabular}{|c|c|c|c|c|c|}
\hline \multirow[b]{2}{*}{ Regressor } & \multicolumn{5}{|c|}{ Binary Probit Estimates } \\
\hline & $\begin{array}{l}\text { EXPECT } \\
\text { (1) }\end{array}$ & $\begin{array}{l}\text { WRITTEN } \\
\text { (2) }\end{array}$ & $\begin{array}{l}\text { WRITGT1 } \\
\text { (3) }\end{array}$ & $\begin{array}{l}\text { WRITGT2 } \\
(4)\end{array}$ & $\begin{array}{l}\text { Ordered Probit } \\
\text { Estimates } \\
(5)\end{array}$ \\
\hline EXP & $\begin{array}{l}5.5 \mathrm{E}-3 \\
(.07)\end{array}$ & $\begin{array}{l}-.016 \\
(1.33)\end{array}$ & $\begin{array}{l}-.018 \\
(1.31)\end{array}$ & $\begin{array}{l}-.018 \\
(1.06)\end{array}$ & $\begin{array}{c}-8.6 \mathrm{E}-3 \\
(2.65)\end{array}$ \\
\hline EXPSQ & $\begin{array}{c}-1.9 \mathrm{E}-4 \\
(.88)\end{array}$ & $\begin{array}{l}1.7 \mathrm{E}-4 \\
(.65)\end{array}$ & $\begin{array}{l}2.2 \mathrm{E}-4 \\
(.71)\end{array}$ & $\begin{array}{l}2.1 \mathrm{E}-4 \\
(.55)\end{array}$ & $\ldots$ \\
\hline EDUC & $\begin{array}{l}9.0 \mathrm{E}-3 \\
(.17)\end{array}$ & $\begin{array}{c}-.014 \\
(.22)\end{array}$ & $\begin{array}{l}-.118 \\
(1.64)\end{array}$ & $\begin{array}{l}-.155 \\
(1.77)\end{array}$ & $\begin{array}{r}.021 \\
(1.64)\end{array}$ \\
\hline EDUCSQ & $\begin{array}{c}-1.3 \mathrm{E}-4 \\
(.06)\end{array}$ & $\begin{array}{l}1.6 \mathrm{E}-3 \\
(.64)\end{array}$ & $\begin{array}{l}5.6 \mathrm{E}-3 \\
(2.00)\end{array}$ & $\begin{array}{l}6.9 \mathrm{E}-3 \\
(2.02)\end{array}$ & $\ldots$ \\
\hline TENURE & $\begin{array}{l}3.2 \mathrm{E}-3 \\
(.33)\end{array}$ & $\begin{array}{r}.044 \\
(3.99)\end{array}$ & $\begin{array}{r}.062 \\
(4.80)\end{array}$ & $\begin{array}{r}.059 \\
(3.78)\end{array}$ & $\begin{array}{r}.024 \\
(5.41)\end{array}$ \\
\hline TENSQ & $\begin{array}{l}2.4 \mathrm{E}-4 \\
(.71)\end{array}$ & $\begin{array}{c}-8.3 \mathrm{E}-4 \\
(2.16)\end{array}$ & $\begin{array}{c}-1.2 \mathrm{E}-3 \\
(2.68)\end{array}$ & $\begin{array}{c}-9.4 \mathrm{E}-4 \\
(1.85)\end{array}$ & $\ldots$ \\
\hline MARRIED & $\begin{array}{r}.107 \\
(1.76)\end{array}$ & $\begin{array}{l}-.113 \\
(1.51)\end{array}$ & $\begin{array}{l}-.150 \\
(1.69)\end{array}$ & $\begin{array}{l}-.168 \\
(1.55)\end{array}$ & $\begin{array}{l}-.098 \\
(1.31)\end{array}$ \\
\hline HEAD & $\begin{array}{c}-.038 \\
(.64)\end{array}$ & $\begin{array}{c}.123 \\
(1.64)\end{array}$ & $\begin{array}{r}.089 \\
(1.00)\end{array}$ & $\begin{array}{c}-.036 \\
(.32)\end{array}$ & $\begin{array}{r}.118 \\
(1.55)\end{array}$ \\
\hline FEMALE & $\begin{array}{c}.112 \\
(1.91)\end{array}$ & $\begin{array}{r}.207 \\
(2.83)\end{array}$ & $\begin{array}{c}.171 \\
(1.97)\end{array}$ & $\begin{array}{c}.155 \\
(1.41)\end{array}$ & $\begin{array}{r}.177 \\
(2.42)\end{array}$ \\
\hline BLACK & $\begin{array}{l}-.103 \\
(1.40)\end{array}$ & $\begin{array}{l}.043 \\
(.48)\end{array}$ & $\begin{array}{l}.061 \\
(.57)\end{array}$ & $\begin{array}{l}.029 \\
(.20)\end{array}$ & $\begin{array}{l}.034 \\
(.38)\end{array}$ \\
\hline OTHRACE & $\begin{array}{l}-.182 \\
(1.43)\end{array}$ & $\begin{array}{c}.281 \\
(1.97)\end{array}$ & $\begin{array}{c}.190 \\
(1.14)\end{array}$ & $\begin{array}{l}.189 \\
(.95)\end{array}$ & $\begin{array}{r}.212 \\
(1.46)\end{array}$ \\
\hline NUMCHILD & $\begin{array}{l}-.021 \\
(1.06)\end{array}$ & $\begin{array}{r}.024 \\
(1.02)\end{array}$ & $\begin{array}{l}.022 \\
(.78)\end{array}$ & $\begin{array}{l}4.4 \mathrm{E}-3 \\
(.12)\end{array}$ & $\begin{array}{l}.015 \\
(.63)\end{array}$ \\
\hline NUMEARN & $\begin{array}{l}.020 \\
(.78)\end{array}$ & $\begin{array}{r}.070 \\
(2.28)\end{array}$ & $\begin{array}{r}.097 \\
(2.69)\end{array}$ & $\begin{array}{r}.150 \\
(3.48)\end{array}$ & $\begin{array}{r}.083 \\
(2.74)\end{array}$ \\
\hline PRTPREV & $\begin{array}{l}.212 \\
(2.46)\end{array}$ & $\begin{array}{l}.108 \\
(.94)\end{array}$ & $\begin{array}{r}.157 \\
(1.12)\end{array}$ & $\begin{array}{l}.070 \\
(.35)\end{array}$ & $\begin{array}{l}.095 \\
(.83)\end{array}$ \\
\hline HINS & $\begin{array}{r}.331 \\
(6.05)\end{array}$ & $\begin{array}{r}.385 \\
(5.36)\end{array}$ & $\begin{array}{r}.369 \\
(4.15)\end{array}$ & $\begin{array}{r}.519 \\
(4.14)\end{array}$ & $\begin{array}{r}.426 \\
(6.07)\end{array}$ \\
\hline CLOSING & $\begin{array}{r}.355 \\
(8.05)\end{array}$ & $\begin{array}{l}.167 \\
(3.07)\end{array}$ & $\begin{array}{r}.408 \\
(6.14)\end{array}$ & $\begin{array}{r}.453 \\
(5.30)\end{array}$ & $\begin{array}{r}.223 \\
(3.95)\end{array}$ \\
\hline RESID & $\begin{array}{c}-.033 \\
(.66)\end{array}$ & $\begin{array}{r}.137 \\
(2.16)\end{array}$ & $\begin{array}{c}.165 \\
(2.16)\end{array}$ & $\begin{array}{l}.112 \\
(1.14)\end{array}$ & $\begin{array}{r}.131 \\
(2.03)\end{array}$ \\
\hline STEUNION & $\begin{array}{l}3.7 \mathrm{E}-3 \\
(.95)\end{array}$ & $\begin{array}{l}6.7 \mathrm{E}-3 \\
(1.41)\end{array}$ & $\begin{array}{l}7.1 \mathrm{E}-3 \\
(1.27)\end{array}$ & $\begin{array}{c}.018 \\
(2.52)\end{array}$ & $\begin{array}{l}8.8 \mathrm{E}-3 \\
(1.91)\end{array}$ \\
\hline RTWORK & $\begin{array}{l}.044 \\
(.71)\end{array}$ & $\begin{array}{l}-.121 \\
(1.54)\end{array}$ & $\begin{array}{l}-.246 \\
(2.61)\end{array}$ & $\begin{array}{l}-.148 \\
(1.21)\end{array}$ & $\begin{array}{l}-.129 \\
(1.68)\end{array}$ \\
\hline URATE & $\begin{array}{l}1.0 \mathrm{E}-3 \\
(.04)\end{array}$ & $\begin{array}{c}-3.9 \mathrm{E}-3 \\
(.14)\end{array}$ & $\begin{array}{c}-4.5 \mathrm{E}-3 \\
(.14)\end{array}$ & $\begin{array}{l}7.2 \mathrm{E}-3 \\
(.17)\end{array}$ & $\begin{array}{l}2.9 \mathrm{E}-3 \\
(.11)\end{array}$ \\
\hline AREARATE & $\begin{array}{c}-9.3 \mathrm{E}-3 \\
(.87)\end{array}$ & $\begin{array}{l}-.016 \\
(1.19)\end{array}$ & $\begin{array}{l}-.017 \\
(1.08)\end{array}$ & $\begin{array}{l}-.042 \\
(2.13)\end{array}$ & $\begin{array}{l}-.023 \\
(1.73)\end{array}$ \\
\hline
\end{tabular}


Table A1 (Continued)

\begin{tabular}{lccccc}
\hline & \multicolumn{5}{c}{ Binary Probit Estimates } \\
\cline { 2 - 6 } & $\begin{array}{c}\text { EXPECT } \\
\text { Regressor }\end{array}$ & $\begin{array}{c}\text { WRITTEN } \\
(1)\end{array}$ & $\begin{array}{c}\text { WRITGT1 } \\
(2)\end{array}$ & $\begin{array}{c}\text { WRITGT2 } \\
(4)\end{array}$ & $\begin{array}{c}\text { Ordered Probit } \\
\text { Estimates } \\
(5)\end{array}$ \\
\hline INDCHG & .015 & .023 & $2.0 \mathrm{E}-3$ & -.022 & $-4.8 \mathrm{E}-3$ \\
& $(1.29)$ & $(1.58)$ & $(.11)$ & $(1.00)$ & $(.46)$ \\
OCCRATE & $8.5 \mathrm{E}-3$ & $9.2 \mathrm{E}-3$ & -.031 & -.057 & .010 \\
& $(.84)$ & $(.73)$ & $(2.05)$ & $(2.74)$ & $(.99)$ \\
INDUNION & $6.0 \mathrm{E}-3$ & $6.1 \mathrm{E}-3$ & $-1.6 \mathrm{E}-3$ & $-3.2 \mathrm{E}-3$ & $\ldots$ \\
& $(2.55)$ & $(2.12)$ & $(.46)$ & $(.73)$ & $\ldots$ \\
OCCUNION & $4.0 \mathrm{E}-3$ & $4.5 \mathrm{E}-3$ & $5.8 \mathrm{E}-3$ & $9.0 \mathrm{E}-3$ & $\ldots$ \\
MANDSTE & $(1.77)$ & $(1.57)$ & $(1.69)$ & $(2.02)$ & .253 \\
VOLSTE & .251 & .219 & .243 & .253 & .251 \\
& $(1.81)$ & $(1.43)$ & $(1.41)$ & $(1.22)$ & $(1.71)$ \\
Dependent variable & .073 & .058 & $1.8 \mathrm{E}-3$ & .094 & .064 \\
mean & $(.88)$ & $(.62)$ & $(.02)$ & $(.75)$ & $(.71)$ \\
$\hat{\beta} \bar{X} / \sigma$ & & & & & \\
\hline
\end{tabular}

NOTE.-Regressions are estimated by maximum-likelihood probit. Absolute values of asymptotic $t$ statistics are in parentheses. Binary probit dependent variables equal one if displacement was expected (whether notice was formal or informal) (EXPECT); written advance notice was received (WRITTEN); more than 1 month's written advance notice was received (WRITGT1); or more than 2 months' written advance notice was received (WRITGT2). Ordered probit dependent variable ADVTIME is equal to zero if no written advance notice was received; one if less than 1 month's written advance notice was received; two if between 1 and 2 months' written advance notice was received; or three if greater than 2 months' written advance notice received. Some variables are excluded from the ordered probit model because of their high collinearity with other included variables.

\section{References}

Addison, John, and Portugal, Pedro. "The Effect of Advance Notification of Plant Closings on Unemployment." Industrial and Labor Relations Review 41 (October 1987): 3-16. (a) . "On the Distributional Shape of Unemployment Duration." Review of Economics and Statistics 69 (August 1987): 520-26. (b) . "Advance Notice and Unemployment: New Evidence from the 1988 Displaced Worker Survey." Unpublished manuscript. Columbia: University of South Carolina, August 1989.

Berenbeim, Ronald E. Company Programs to Ease Plant Shutdowns. New York: Conference Board, 1986.

Brown, Sharon. "How Often Do Workers Receive Advance Notice of Layoffs?" Monthly Labor Review 110 (June 1987): 13-17.

Ehrenberg, Ronald, and Jakubson, George. Advance Notice Provisions in Plant Closing Legislation. Kalamazoo, Mich.: W. E. Upjohn Institute for Employment Research, 1988.

Fallick, Bruce C. "Advance Notice and Destructive Attrition." Unpublished manuscript. Los Angeles: University of California, Los Angeles, March 1991.

Flaim, Paul 0., and Sehgal, Ellen. "Displaced Workers of 1979-83: How Well Have They Fared?" Monthly Labor Review 108 (June 1985): 3-16. 
Folbre, Nancy; Leighton, Julia; and Roderick, Melissa. "Plant Closings and Their Regulation in Maine, 1971-1981." Industrial and Labor Relations Review 37 (January 1984): 185-96.

Horvath, Francis W. "The Pulse of Economic Change: Displaced Workers of 1981-5." Monthly Labor Review 110 (June 1987): 3-12.

Howland, Marie, and Peterson, George. "Labor Market Conditions and the Reemployment of Displaced Workers." Industrial and Labor Relations Review 42 (October 1988): 109-22.

Kletzer, Lori G. "Industry Wage Differentials and Permanent Job Loss: Do Workers Displaced from High-Wage Industries Have Longer Durations of Joblessness?" Unpublished manuscript. Williamstown, Mass.: Williams College, May 1989.

Kokkelenberg, Edward, and Sockell, Donna. "Union Membership in the United States." Industrial and Labor Relations Review 38 (July 1985): 497-543.

Lancaster, Tony. "Econometric Methods for the Duration of Unemployment." Econometrica 47 (July 1979): 939-56.

Podgursky, Michael, and Swaim, Paul. "Duration of Joblessness following Job Displacement." Industrial Relations 26 (Fall 1987): 213-26.

Portugal, Pedro, and Addison, John. "Advance Notification and the Job Search Process: Notification Interval, Unemployment Time Saved, and Absence of Intervening Spell of Joblessness." Unpublished manuscript. Columbia: University of South Carolina, March 1989.

Ruhm, Christopher J. "Are Workers Permanently Scarred by Job Dis placements?" American Economic Review 81 (March 1991): 319-24. (a)

. "Advance Notice, Job Search, and Postdisplacement Earnings." Unpublished manuscript. Greensboro: University of North Carolina, June 1991. (b)

Swaim, Paul, and Podgursky, Michael. "Advance Notice and Job Search: The Value of an Early Start." Journal of Human Resources 25 (Spring 1990 ): 147-78.

Topel, Robert. "Specific Capital and Unemployment: Measuring the Costs and Consequences of Job Loss." Carnegie-Rochester Conference Series on Public Policy 33 (1990): 181-214.

U.S. Department of Commerce. Statistical Abstract of the United States, 1988. Washington, D.C.: U.S. Government Printing Office, 1988.

U.S. Department of Labor. Employment and Earnings. Washington, D.C.:

U.S. Government Printing Office, May 1988.

U.S. General Accounting Office. Limited Advance Notice and Assistance Provided Dislocated Workers. GAO/HRD-87-105. Washington, D.C.: U.S. Government Printing Office, 1987. 